\title{
Geocronologia de rochas gnáissico-migmatíticas e sienograníticas do Núcleo Setuva (Pr): implicações tectônicas
}

\author{
Oswaldo Siga Junior ${ }^{1}$, Miguel Ângelo Stipp Basei ${ }^{1}$, Claudia Regina Passarelli ${ }^{1}$, Ossama \\ Mohamed Harara ${ }^{1}$, Kei Sato ${ }^{1}$, Leonardo Fadel Cury ${ }^{1} \&$ Hélcio José dos Prazeres Filho ${ }^{1}$
}

\begin{abstract}
Resumo O Núcleo Setuva localiza-se no leste do Estado do Paraná, a sul da Zona de Cisalhamento Lancinha. Apresenta forma alongada, aproximadamente sigmoidal, e ocorre em meio as seqüências metassedimentares da Formação Capirú. É representado por rochas gnáissico-migmatíticas, em sua porção sul, e graníticas (sieno a monzograníticas e granodioríticas) heterogeneamente deformadas (protomiloníticas a miloníticas), no setor centro-norte. O padrão isotópico U-Pb (zircão) permite reconhecer em terrenos gnáissico-migmatíticos do Núcleo Setuva (setor sul), idades arqueanas (3.200 - 3.000Ma) e em sienogranitos miloníticos (setor norte), idades do arqueano tardio ( $\sim 2.650 \mathrm{Ma})$ e Paleoproterozóico ( $\sim 2.100 \mathrm{Ma})$. Esses valores, obtidos no intercepto superior de diagramas concórdia, se mostram imprecisos e referem-se a idades de zircões que apresentam bordas de sobrecrescimento. As idades obtidas no intercepto inferior desses diagramas, também imprecisas, relacionam-se ao Neoproterozóico. Distingue-se deste padrão isotópico os zircões relativos aos sienogranitos protomiloníticos da porção central do Núcleo Setuva, que não apresentam feições de sobrecrescimento e têm seus dados analíticos posicionados próximos ao intercepto superior do diagrama Concórdia, com idade de formação relacionada ao paleoproterozóico $(2.140 \pm 8 \mathrm{Ma})$. Nestes sienogranitos (porção central do Núcleo Setuva), a tectônica neoproterozóica só foi caracterizada através das metodologias $\mathrm{K}-\mathrm{Ar} \mathrm{e}^{40} \mathrm{Ar}^{-39} \mathrm{Ar}$ em biotitas ( $\sim 590 \mathrm{Ma})$, sugerindo tal época como relativa ao resfriamento dessas rochas a temperaturas inferiores a 250 $300^{\circ} \mathrm{C}$. Tal quadro se mostra coerente com o padrão estrutural, relacionado a uma tectônica de cisalhamentos, inicialmente de baixo a médio ângulo (cavalgamentos), seguidos por sistemas transcorrentes e dobramentos tardios. Essa tectônica parece ser a responsável pelo fatiamento, aloctonia e colocação lado a lado de terrenos oriundos de diferentes níveis crustais durante o Neoproterozóico. Acredita-se, com base na continuidade física (porção oriental), litotipos presentes e padrão isotópico bastante similar, que o Núcleo Setuva represente uma extensão a norte do denominado Complexo Atuba.
\end{abstract}

Palavras Chave: Geocronologia; U-Pb (zircão); terrenos policíclicos; Núcleo Setuva.

\begin{abstract}
Geochronology of gneiss migmatitic and syenogranite rocks of the Setuva Nucleus (Pr): tectonic implications The Setuva Nucleus is located in the eastern part of Paraná, south of the Lancinha Shear Zone. It occurs as an elongated sygmoidal shape within metassedimentary sequences of the Capirú Formation. It is represented by promomylonitic to mylonitic rocks, predominating gneissic-migmatitic lithotypes in the southern portion and syenogranitic to monzogranodioritic rocks in the central - northern portions. The $\mathrm{U}-\mathrm{Pb}$ isotopic pattern in zircons characterizes the formation of gneissic-migmatitic rocks during the Archean (3.200-3.000Ma), and the proto - to mylonitic syenogranitic lithotypes (northern portions) during the Archean $(\sim 2.650 \mathrm{Ma}))$ and Paleoproterozoic $(\sim 2.100 \mathrm{Ma})$. In general, the analyzed zircons show overgrowths of doubtful Neoproterozoic ages, obtained in the lower intercepts of Concordia Diagram. On the other hand, the zircons of protomylonitic syenogranite rocks (Setuva's central sector) don't show any overgrowth features. U-Pb analytical data, when plotted in corcodia diagram, cluster close to the lower intercept, yielding $2.140 \pm 8 \mathrm{Ma}$. Such value, related to the paleoproterozoic, is interpreted as the time of zircon crystallization and consequently formation of the syenogranitic rocks. Aditionally, K-Ar and ${ }^{40} \mathrm{Ar}-{ }^{39} \mathrm{Ar}$ analyses carried out in biotites of theses rocks indicated Neoproterozoic ages (590Ma). Such values indicate emplacement according to isotherms of temperatures lower than $250^{\circ} \mathrm{C}-300^{\circ} \mathrm{C}$ during the Neoproterozoic. The geochronological pattern joined with the structural pattern suggests that the emplacement, largely controlled by shearing, at upper crustal levels occurred during the Neoproterozoic. The initial, low-angle tectonics, associated with transcurrent shear systems and later folding, should be responsible for the allochthony of these terrains and consequent emplacement at upper crustal levels. Such isotopic pattern is very similar to the observed for the Atuba Complex gneissicmigmatitic terrains located south of Setuva.
\end{abstract}

Keywords: geochronology, U-Pb (zircon), polycyclic terrains, Setuva Nucleus.

INTRODUÇÃo Os terrenos pré-Cambrianos do setor leste do Paraná e sudeste de São Paulo são re- presentados, em grande parte, por seqüências metavulcanossedimentares (porção sul da Faixa Ribeira de 
Almeida et al., 1973; ou mais especificamente Faixa de Dobramentos Apiaí de Hasui et al., 1975). Destaca-se, no âmbito da Faixa de Dobramentos Apiaí, expressivo magmatismo granítico, bem como terrenos granito-gnáissicos admitidos como altos do embasamento, representados pelos Núcleos do Tigre (que inclui os núcleos Perau e Anta Gorda) e Betara (que inclui os núcleos Ouro Fino e Alto Açungui), segundo Fritzons Jr et al. (1982). Esses terrenos são balizados a sul - sudeste, através da Zona de Cisalhamento Lancinha, com rochas gnáissico-migmatíticas pertencentes ao Complexo Atuba (Siga Jr. et al., 1995), que têm como cobertura as seqüências metassedimentares das formações Capiru e Turvo-Cajati, conforme figura 1.

O Núcleo Setuva admitido, conforme contexto acima, como alto do embasamento, localiza-se a sul da Zona de Cisalhamento Lancinha, no âmbito dos terrenos gnáissico-migmatíticos pertencentes ao Complexo Atuba (Siga Junior et al., 1995 e Kaulfuss, 2001).

Os trabalhos relacionados ao Núcleo Setuva mencionam, de modo geral, o predomínio de rochas gnáissicas, gnáissico-migmatíticas e mais raramente graníticas. Os estudos macro e microscópicos realizados caracterizam a presença de litotipos gnáissicos e gnáissico-migmatíticos principalmente no setor sul deste núcleo, e o predomínio de termos graníticos heterogeneamente deformados (proto a miloníticos) em toda porção centro-norte.

Os estudos isotópicos realizados no Centro de Pesquisas Geocronológicas do Instituto de Geociências da Universidade de São Paulo (CPGeo-IGc-USP) envolveram rochas gnáissico-migmatíticas e sienograníticas do Núcleo Setuva ,utilizando-se principalmente a metodologia U-Pb, em zircões e, subordinadamente, Sm-Nd, e K-Ar $/{ }^{40} \mathrm{Ar}-{ }^{39} \mathrm{Ar}$. Teve como principal objetivo o melhor entendimento relativo a evolução geodinâmica deste setor, envolvendo épocas relacionadas a diferenciação manto-crosta(idades modelo $\mathrm{Sm}-\mathrm{Nd})$, formação de crosta continental(U-Pb,zircão) e posterior história termal da região $\left(\mathrm{K}-\mathrm{Ar} /{ }^{40} \mathrm{Ar}-{ }^{39} \mathrm{Ar}\right)$.

SÍNTESE DOS CONHECIMENTOS Os trabalhos geológicos do Pré-cambriano paranaense foram motivados desde cedo devido as ocorrências de importantes jazimentos minerais na região (chumbo, prata, ouro, cobre, cassiterita, wollastonita, sheelita, mármore, fluorita, barita, calcita, esfalerita e rochas ornamentais). Durante a segunda metade do século XIX até o final da década de 40, os trabalhos realizados envolveram principalmente o reconhecimento geológico desses terrenos. Neste período surgem os primeiros mapas regionais e a denominação de "Série Assunguy" para as rochas metassedimentares do leste paranaense. Destacam-se, neste período, as pesquisas realizadas por Derby (1878), Oliveira (1927), Carvalho e Pinto (1937), Oliveira e Leonardos (1943) e Maack (1947). Na década de 50 inicia-se uma nova fase, onde os estudos envolvendo relações estratigráficas, tectônicas, e mapeamentos geológicos (locais e regionais) são priorizados. A partir deste período várias foram as pro- posições estratigráficas do pré-cambriano paranaense, incluindo a adição ou retirada de formações, modificações no empilhamento, áreas de ocorrência, atingindo mais de quarenta (40) colunas geológicas sugeridas, sintetizadas em Fiori (1990) e Fassbinder (1996). Dentre os trabalhos de cartografia geológica, síntese e integração regional destacam-se os efetuados na década de 60 pela Comissão da Carta Geológica do Paraná, os de Marini et al. (1967), Kaefer e Algarte (1972), Batolla Jr. et al. (1981), Takahashi et al. (1981), Fritzons Jr et al. (1982), Biondi (1983), Chiodi Filho (1984), Hasui et al. (1975 e 1984), Biondi et al. (1989) e Silva et al. (1998a e b). Os estudos envolvendo análises faciológicas, contexto geológico-estrutural e modelamento tectônico referem-se principalmente a Campanha et al. (1987), Soares (1987), Fiori (1990 e 1991), Althoff e Fiori (1991), Campanha (1991), Fiori et al. (1987a, b e c), Reis Neto (1994), Daitx (1996) e Yamato (1999).

No reconhecimento e nas tentativas de posicionar os núcleos gnáissico-migmatíticos (Setuva, Betara e Tigre), que ocorrem em meio as seqüências metavulcanossedimentares, destacam-se os trabalhos de Bigarella e Salamuni (1956), Marini (1970), Ebert (1971), Schöll et al (1980), Popp et al. (1979), Piekarz (1981, 1984) Salamuni (1991), Althoff e Fiori (1991), Basei et al. (1992); Martin et al. (1994), Silva et al. (1998a e b), Yamato (1999) e Kaulfuss (2001).

A Formação Setuva foi descrita pela primeira vez por Bigarella e Salamuni (1956) e individualizada como formação basal do Grupo Açungui, sendo sua extensão, na época, restrita ao Anticlinal do Setuva. Os mapeamentos geológicos executados pela Comissão da Carta Geológica do Paraná, na década de 60, ampliam sua área de ocorrência aos Anticlinais do Betara (Ouro Fino e Alto Açungui) e Tigre (Anta Gorda e Perau). Marini (1970) sugere que a Formação Setuva faça parte do embasamento do Grupo Açungui e caracteriza a separação desta através de hiato metamórfico e estrutural. Ebert (1971), baseado em análises metamórficas de amostras coletadas ao longo da Estrada da Ribeira, no Anticlinal do Setuva, restringe a Formação Setuva aos xistos e quartzitos, posicionando-a na base do Grupo Açungui. O autor engloba as rochas gnáissicas como Grupo Pré-Setuva, subdividindo-as em uma seqüência de paragnaisses e um complexo granítico intrusivo, posteriormente milonitizado. Schöll et al. (1980) também restringem a Formação Setuva aos xistos e quartzitos, porém retiram a mesma do Grupo Açungui, baseado no hiato metamórfico - estrutural já constatado por Marini (1970). Esses autores também separam os terrenos gnáissicos no que denominam de Complexo Pré-Setuva, subdividindo-o em uma unidade superior de paragnaisses e uma inferior de migmatitos e granitos de anatexia, parcialmente milonitizados. Popp et al. (1979), baseados em estudos desenvolvidos no Anticlinal do Betara elevam a Formação Setuva a categoria de Grupo. Esses autores incluem no Grupo Setuva tanto os gnaisses (Formação Meia Lua) quanto os quartzitos e xistos (Formação Betara), denominações essas adotadas por Salamuni (1991). Piekarz 


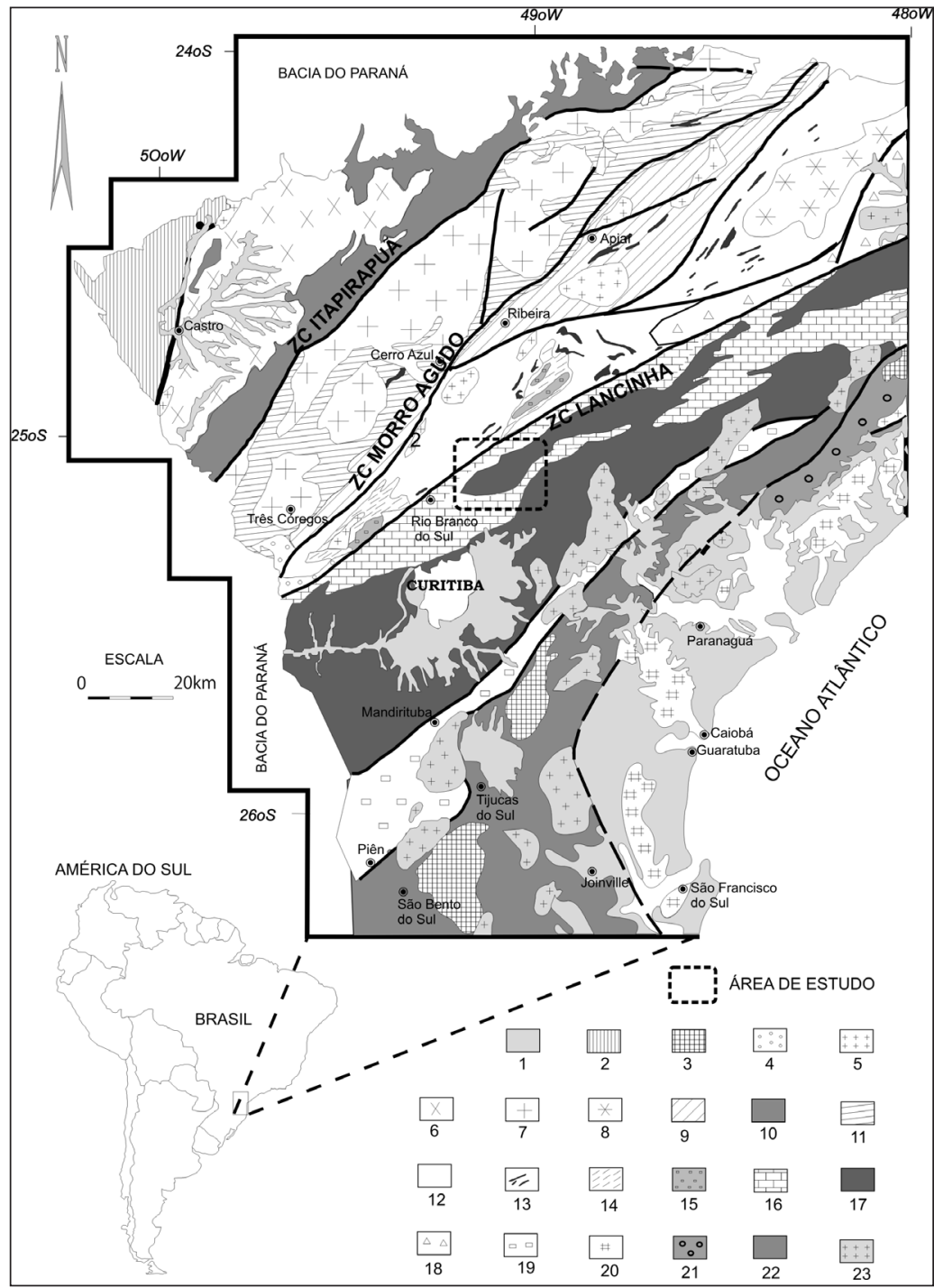

Legenda:

(1) -Depósitos Cenozóicos; (2) - Grupo Castro (c.540Ma); (3) - Bacias de Guaratubinha, Campo Alegre ( c.600Ma); (4) - Grupo Camarinha (Eo-Cambriano - c.545Ma); (5) - Granitos Sin à Pós Colisionais [c.560Ma]; (6) - Complexo Batolitico Cunhaporanga [c.600-590Ma]; (7) - Batólito Três Córregos e corpos graníticos associados [c.630-600Ma], (8) - Complexo Batolitico Agudos Grandes [c.620-600Ma]; (9) Grupo Lajeado / Seqüência Antinha (Neoproterozóico?); (10) - Formação Itaiacoca [c. 1000-900Ma] e Formação Abapã(c.630Ma); (11) - Formação Água Clara [c.1500-1450Ma]; (12) - Formação Votuverava [c.1450Ma]; (13) -Metabasitos indiferenciados; (14) - Seqüencias Perau e Betara [c.1500-1450Ma]; (15) - Granitóides Alcalinos deformados [c.1750Ma] e granitóides cálcicoalcalinos deformados [c.2100Ma]; (16) - Formações Capirú e Turvo Cajati(Neoproterozóico?); (17) - Complexo Gnáissico-Migmatítico Atuba [épocas de formação:c. 2200-2000Ma / épocas de migmatização e resfriamento regional: c.620600Ma]; (18) - Complexo Embu [épocas de formação: c.2200-2000Ma / épocas de migmatização e resfriamento regional: c.620-600Ma]; (19) - Complexo Rio Piên [c.620-615Ma]; (20) - Complexo Costeiro [c.615-600Ma]; (21) - Cobertura Metassedimentar: Seqüencia Cachoeira [Neoproterozóico?]; (22) - Complexo Granulitico Luis Alves [c.2200-2100Ma]; (23) - Granitos Pós-Colisionais [c.600-580].

Figura 1: Esboço geológico - tectônico do sudeste brasileiro (adaptado de Siga Junior et al. 2002).

(1981) admite para uma parte da seqüência, que ocorre entre Campo Largo e a Mina do Perau origem vulcanossedimentar. Denomina essa seqüência de Perau e a posiciona litoestratigraficamente entre a Formação Setuva (gnaisses, xistos e quartzitos) e o Grupo Açungui.

Observa-se, portanto, uma grande proliferação de denominações e tentativas de correlações estratigráficas advindas de trabalhos nem sempre com a expressão regional necessária.

Os dados geocronológicos pré-existentes nestes terrenos, admitidos como Setuva, referem-se principalmente a um diagrama isocrônico $\mathrm{Rb}$-Sr que inclui xistos, filitos e gnaisses de diferentes afloramentos (Teixeira, 1982). Os pontos analíticos permitiram o traçado de três retas isocrônicas com idades próximas de $1.400 \mathrm{Ma}$, $1.200 \mathrm{Ma}$ e $590 \mathrm{Ma}$, com razões iniciais respectivamente da ordem de $0,717,0,711$ e 0,743 . Os demais dados $\mathrm{Rb}$-Sr referem-se a xistos e filitos admitidos como pertencentes a Formação Setuva, cujas idades convencionais distribuem-se entre aproximadamente $2.100 \mathrm{e}$ $1.100 \mathrm{Ma}$ (Takahashi et al., 1981). Adicionalmente, são disponíveis dois dados K-Ar (Cordani e Bittencourt,
1967), um relativo a uma rocha gnáissica do Núcleo Setuva ( $587 \pm 17 \mathrm{Ma}$, em biotita) e o outro relativo a um filito do Grupo Açungui (560土20Ma, em rocha total).

Pesquisas mais recentes relacionadas ao Núcleo Setuva se devem a Silva et al. (1998a e b); Fiori et al.(2003), que interpretam as rochas gnáissicas deste setor como parte integrante do Complexo Atuba (Siga Jr. et al., 1995), e as rochas metassedimentares, que ocorrem em suas bordas como uma fácies intensamente deformada da Formação Capirú. Yamato (1999) relaciona igualmente as rochas gnáissicas deste núcleo ao Complexo Atuba, porém, incluindo os xistos, quartzitos e metacalcáreos da porção mais externa à Formação Setuva. Kaulfuss (2001) caracteriza a predominância de protomilonitos e milonitos de composição sienogranítica, monzogranítica e granodiorítica e subordinadamente de rochas gnáissico miloníticas (restrita a porção sul do núcleo). O autor (op. cit.) apresenta estudo isotópico nos litotipos gnáissicos e graníticos, utilizandose da metodologia U-Pb em zircões. Caracteriza para esses litotipos uma evolução policíclica, com idades relacionadas ao Arqueano, Paleoproterozóico e Neopro- 
terozóico. Tal padrão isotópico assemelha-se bastante ao descrito por Siga Jr. et al. (1995) para os demais terrenos pertencentes ao Complexo Atuba, representado principalmente por rochas gnaíssico-migmatíticas, graníticas e anfibolíticas heterogeneamente deformadas. Com base na continuidade física, nos litotipos presentes e no padrão isotópico, o Núcleo Setuva representa uma extensão a norte do denominado Complexo Atuba.

CARACTERÍSTICAS GEOLÓGICAS O Núcleo Setuva é representado por rochas graníticas (s.l.) e gnáissico-migmatíticas, expostas em meio as seqüências metassedimentares (mármores dolomíticos, filitos, quartzitos e xistos) da Formação Capiru (Fig. 2). Este núcleo apresenta forma alongada, aproximadamente sigmoidal, com direção geral NE-SW e localiza-se a sul de importante e expressiva zona de cisalhamento, denominada Lancinha. Apresenta contatos tectônicos com as rochas metassedimentares da Formação Capiru, e continuidade física à leste com os terrenos gnáissico-migmatíticos, graníticos e anfibolíticos pertencentes ao Complexo Atuba. Os Núcleos Betara e Tigre, distintamente, localizam-se a norte da Zona de Cisalhamento Lancinha e fazem contatos respectivamente com as seqüências metavulcanossedimentares das Formações Betara e Perau.

No Núcleo Setuva predominam litotipos gnáissico-migmatíticos em sua porção sul e graníticos (sienogranitos, granodioritos e monzogranitos) em sua porção centro-norte, ambos com estruturas protomiloníticas e miloníticas. Os litotipos gnáissicomigmatíticos se apresentam ,de modo geral, intensa- mente intemperizados, e são caracterizados por rochas centimétrica a milimetricamente bandadas, alternando níveis francamente quartzo-feldspáticos com níveis avermelhados a ocres. Injeções de material quartzofeldspático, com dimensões e formas variadas ocorrem tanto concordantes como discordantes do bandamento gnáissico-migmatítico. Esses litotipos ocorrem principalmente ao longo da BR-476 (Estrada da Ribeira), cerca de $2 \mathrm{Km}$ a norte da cidade de Bocaiúva do Sul. De um modo geral, essas rochas gnáissicas apresentam uma marcante foliação milonítica (NE-SW) subparalela ao bandamento composicional (Figs. 3a e 3b).

No setor centro-norte deste núcleo esses litotipos fazem contato, através de zonas de cisalhamento de baixo ângulo, com rochas sienograníticas proto a miloníticas, de cor normalmente cinza-rosadas, ricas em porfiroclastos de K-feldspato, com formas ovaladas e dimensões que variam de submilimétrica a centimétrica. São rochas a K-feldspato, quartzo, plagioclásio, biotita, além de clorita, sericita / muscovita (Fig. 4). Os principais minerais acessórios são zircão, apatita, titanita, allanita, opacos, além de epidoto e calcita. A foliação observada nesses sienogranitos é de baixo ângulo, definida pelo estiramento mineral (quartzo, feldspato), orientação dos minerais micáceos (biotita e sericita) e presença de bandas de quartzo policristalinos (Figs. 4 e 5).

Adicionalmente, ocorrem rochas de composição granodiorítica (setor oeste do núcleo) e monzograníticas (extremo norte do núcleo) com estruturas protomiloníticas e miloníticas. Apresentam, de modo geral, granulação fina, sendo constituídas por K-felds-

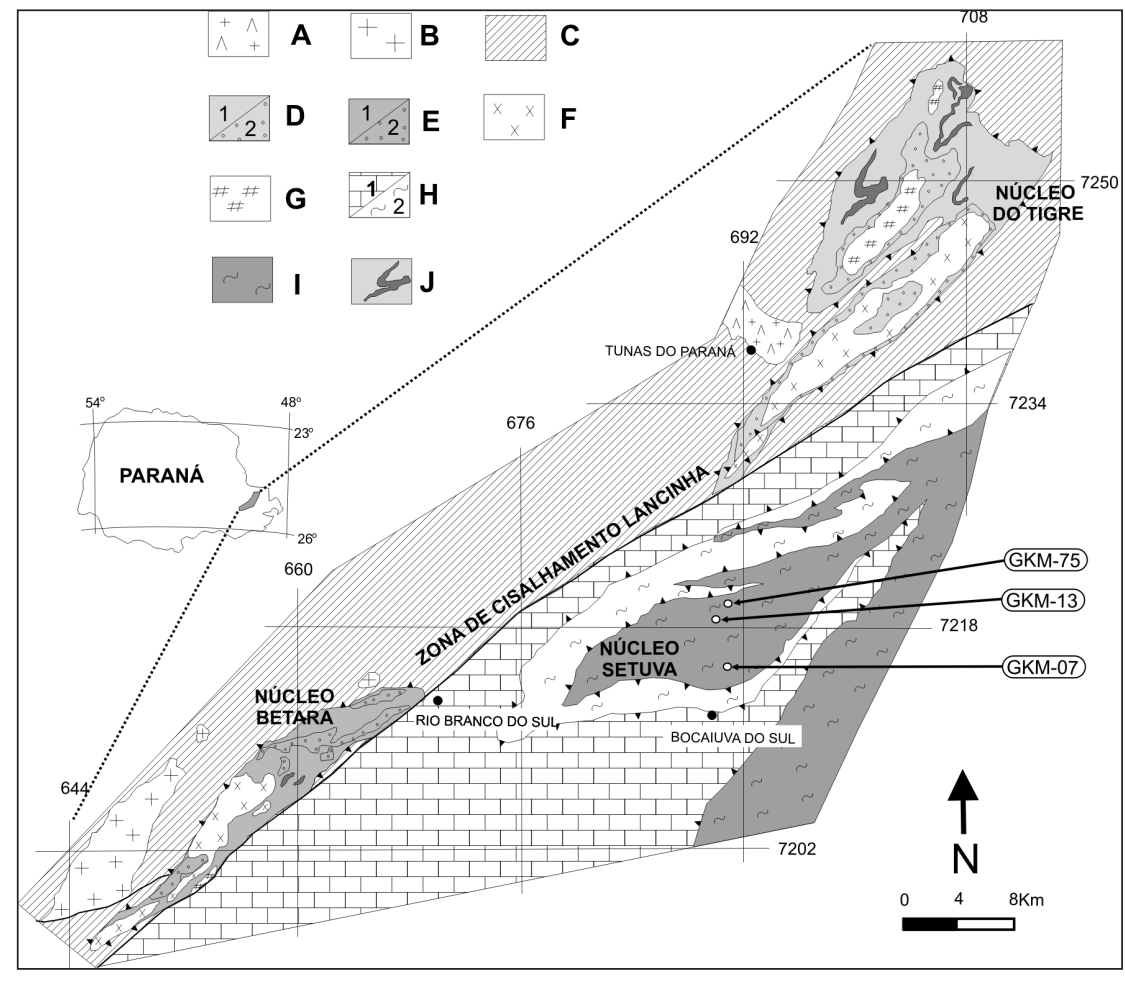

Figura 2: Esboço Geológico dos Núcleos Betara, Tigre e Setuva (Modificado de Kaulfuss, 2001).
(A) Complexo Alcalino Tunas [Mesozóico]: sienitos, álcali sienitos e brechas vulcânicas; (B) Granitóides Tardi-Tectônicos [Neoproterozóico] : sienogranitos, monzogranitos, quartzo-sienitos e alcali-feldspato-sienitos; (C) Formação Votuverava [Mesoproterozóico] : filitos, metaritimitos, metasiltitos, metamargas, e quartzitos ; (D) Formação Perau [Mesoproterozóico] : bitotia e anfibólio xistos, mármores dolomíticos e filitos (1), quartzitos micáceos (2); (E) Formação Betara [Mesoproterozóico] : xistos, xistos ferruginosos, metamargas, e formações ferríferas (1) ,quartzitos (2); (F) : Granitóides Deformados [Paleoproterozóico Superior: Estateriano]: sienogranitos proto a miloníticos; $(G)$ Granitóides Deformados [Paleoproterozóico com heranças do Arqueano ] : monzonitos, granodioritos, quartzo-monzonitos, quartzogranodioritos; (H) Formação Capirú [Neoproterozóico?]: metacalcários dolomíticos, metaritimitos, filitos e quartzitos (1), xistos e quartzitos(2); (I) Complexo Atuba [Paleoproterozóico /Migmatização Neoproterozóica]: gnaisses, gnaisses-migmatíticos, granitóides deformados e anfibolitos; (J) Metabásicas e Anfibolitos indiferenciados. 


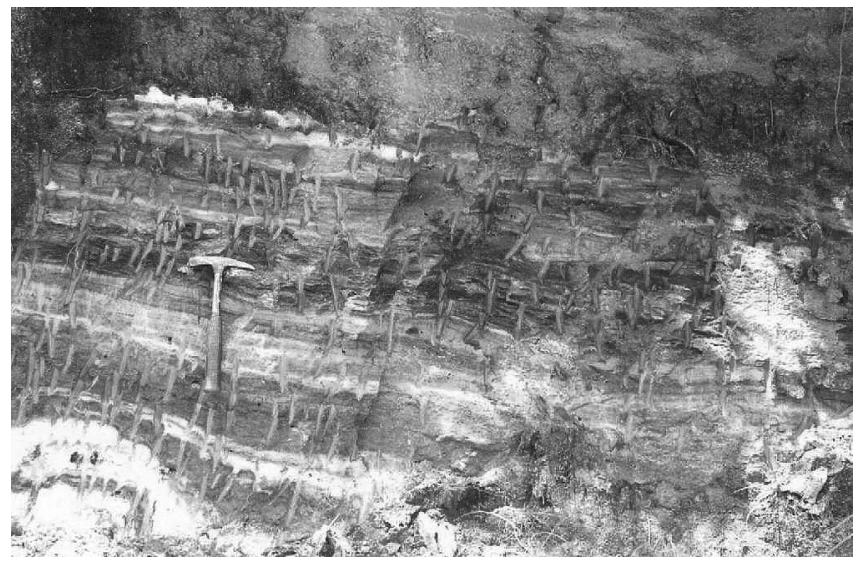

Figura 3a: Gnaisses migmatíticos com bandamento centimétrico definido por intercalações de niveis ocres e níveis leucocráticos (GKM-6).

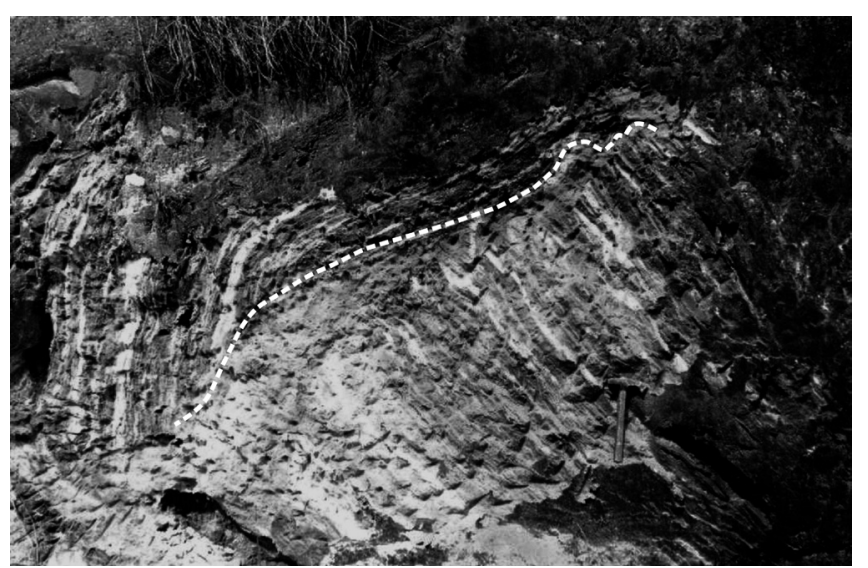

Figura 3b: Gnaisses migmatíticos miloniticos com injeção de material leucocrático discordante. Observar feição sugestiva de cavalgamento.

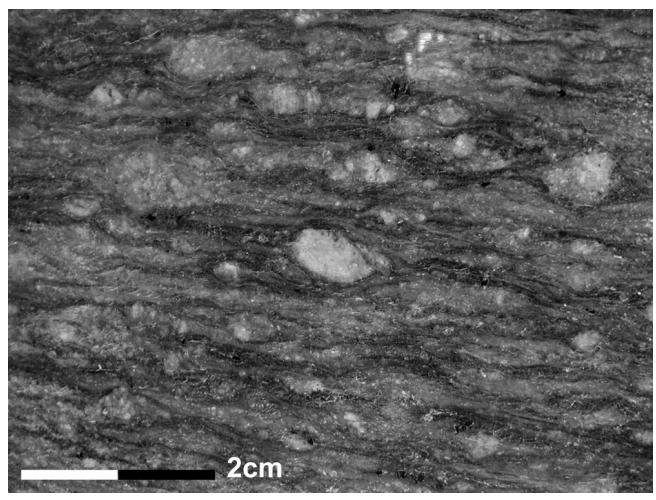

Figura 4: Sienogranito protomilonítico do setor centro-norte do Núcleo Setuva (afloramento GKM-13).

pato (porfiroclastos milimétricos a centímetros), quartzo, plagioclásio e biotita. A marcante foliação proto a milonítica, de baixo a médio ângulo (N40-65E/ 30$40 \mathrm{NW}$ ) é caracterizada pelo estiramento pronunciado dos minerais, ribbons de quartzo e quartzo recristalizado em sombras de pressão de feldspatos. Essa superfícies se mostram muitas vezes afetadas por uma foliação de cisalhamento de alto ângulo (N70-80E / 70$80 \mathrm{NW}$ ), desenvolvida em regime rúptil a rúptil-dúctil .

O padrão estrutural observado nos litotipos protomiloníticos a miloníticos do Núcleo Setuva permite reconhecer uma superfície $\mathrm{Sn}(\mathrm{Sc})$, de baixo a médio ângulo $\left(10^{\circ}\right.$ à $\left.45^{\circ}\right)$, de regime tectônico dúctil, a dúctilrúptil caracterizada por uma textura de aspecto anastomosado, presença de sombras de pressão assimétrica e/ou simétrica, estiramento, lenticularização e recristalização de minerais, quartzo-ribbon, par S-C e dobras falha. As lineações minerais (tipo a) associadas às sombras de pressão assimétricas e superfícies S-C sugerem transporte tectônico de NW para SE, similarmente ao observado por Fiori (1990; 1991) e Kaulfuss (2001). Em alguns dos afloramentos é possível reconhecer uma superfície $(\mathrm{Sn}+1)$, também de baixo a médio ângulo, heterogeneamente desenvolvida, que muitas vezes crenula Sn. Essas superfícies ( $\mathrm{Sn}$ e $\mathrm{Sn}+1)$ se apresentam, de modo geral, onduladas ou mesmo afetadas por dobramentos abertos, cilíndricos, com eixos sub-horizontais e planos axiais com direção geral NE-SW. Associamse a uma clivagem espaçada, normalmente subvertical $(\mathrm{Sn}+2)$, plano axial de dobramentos abertos. Relacionam-se, provavelmente, as antiformas e sinformas regionais. Os planos de cisalhamento de alto ângulo com mergulhos sub-verticais $(\mathrm{Sn}+3)$ apresentam intensidade variável, função da maior ou menor proximidade com as zonas de cisalhamento, a exemplo da Lancinha. Observam-se lenticularizações, redobramentos e recristalizações de minerais, obliterando, por vezes, completamente as foliações de baixo ângulo. Embora possa haver relação quanto a tectônica responsável pela geração das superfícies de clivagem $(\mathrm{Sn}+2)$ e as zonas de cisalhamento $(\mathrm{Sn}+3)$, observa-se que estas últimas truncam regionalmente as estruturas antiformais e sinformais.

Os dados estruturais (Sn) quando tratados em estereograma de igual área (Schmidt Lambert) apresentam concentrações de pólos nos quadrantes NNE e SSE, com planos associados respectivamente a N87W / $47^{\circ} \mathrm{SW}$ e N69E / 39 NW (Fig. 6). Tal comportamento parece estar associado a dobramentos abertos, tardios, com eixos relativamente horizontalizados, e direção geral E-W. Associamse lineações minerais (Lb), que posicionam-se nos domínios $\mathrm{W}$ e $\mathrm{E}$ do diagrama, com baixos caimentos, paralelas aos eixos dos dobramentos tardios.

O padrão estrutural observado é bastante similar ao apresentado por diversos autores para as seqüências metavulcanossedimentares da Faixa Apiaí e Complexo Atuba a exemplo de Fiori (1989, 1991), Siga Jr. et al. (1995), Reis Neto e Soares (1987), Campanha et al. (1987), Salamuni et al. (1993), Fassbinder (1990), Daitx (1996), Silva et al. (1998a), Yamato (1999) e Kaulfuss (2001). É sugestivo de um regime de esforços de natureza compressiva com direção geral, predominantemente NNW - SSE, responsável pela tectônica de cisalhamento e conseqüentemente da complexa compar- 


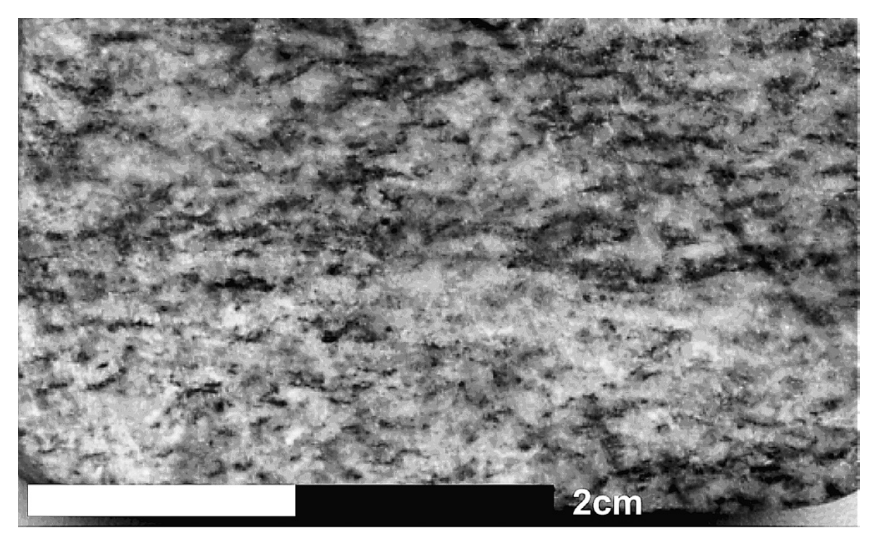

Figura 5: Sienogranito milonítico da porção norte do Núcleo Setuva (afloramento GKM-75).

timentação desses terrenos metavulcanossedimentares.

GEOCRONOLOGIA As análises geocronológicas foram realizadas no Centro de Pesquisas Geocronológicas (CPGeo) do Instituto de Geociências (IGc) da Universidade de São Paulo (USP) e envolveram principalmente os métodos U-Pb (TIMS) e $\mathrm{Pb}-\mathrm{Pb}$ (EVTIMS) em zircões, além dos métodos Sm-Nd (rocha total), $\mathrm{K}-\mathrm{Ar}$ e ${ }^{40} \mathrm{Ar}^{-39} \mathrm{Ar}$ em biotitas. Tais estudos concentraram-se em três afloramentos representados por rochas sienograníticas protomiloníticas (setor central), sienograníticas miloníticas (setor norte) e gnáissico-migmatíticas (setor sul). Esses afloramentos foram selecionados para estudos geocronológicos por representarem as melhores exposições desses litotipos, predomintes

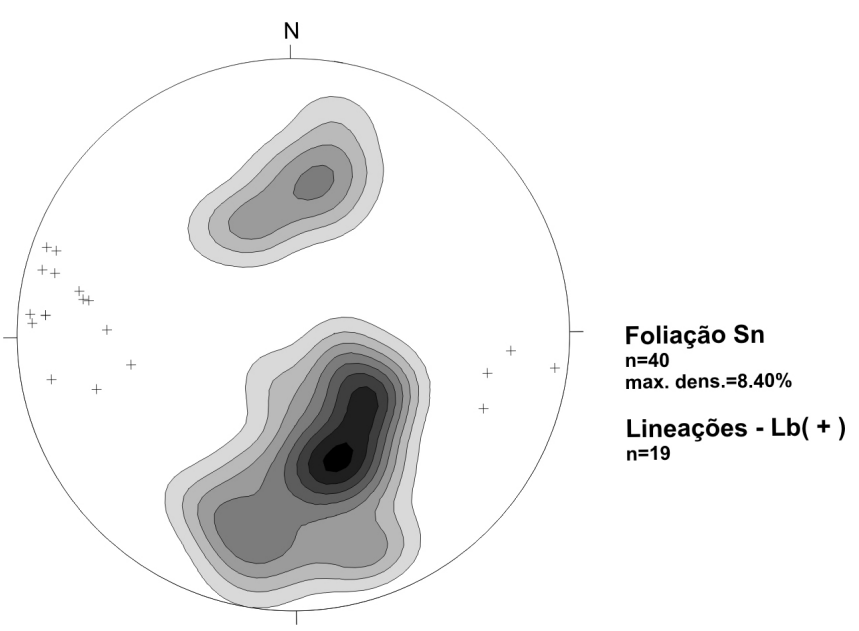

Figura 6: Estereograma de igual área elaborado a partir de pólos de Sn para o Núcleo Setuva.

nas porções norte, central e sul do Núcleo Setuva.

\section{Procedimentos Analíticos}

ANÁLISES U-Pb (TIMS) e Pb-Pb (EV-TIMS) A concentração de zircões para análises U-Pb e Pb-Pb foi realizada utilizando-se de britador de mandíbulas, moinho de discos, conjunto de peneiras, mesa de Wiffley, separador magnético tipo Frantz e líquidos densos (Bromofórmio e Iodeto de metileno). A seleção fina (multigrãos) foi realizada por catação manual sob lupa binocular, utilizando-se para pesagem a relação densidade $v s$. volume. Foram selecionados para análise cerca de 10 à 15 cristais de zircão, que após limpeza $(\mathrm{HCl}$ $+\mathrm{HNO}_{3}$ ), foram dissolvidos em micro-bombas de teflon, sendo o urânio $(\mathrm{U})$ e o chumbo $(\mathrm{Pb})$ separados através de colunas de resina aniônica, segundo procedimentos descritos em Basei et al. (1995), adaptados de Krogh (1973 e 1982) e Parrish (1987). Utilizou-se o traçador (spike) $205 \mathrm{~Pb} / 235 \mathrm{U}$ e o branco total obtido foi da ordem de $10 \mathrm{pg}$. As medições foram realizadas em espectrômetro de massa multi-coletor Finnigan MAT-262. No CPGeo os valores médios medidos para os padrões NBS-981 e NBS-983 são respectivamente de: ${ }^{204} \mathrm{~Pb} /{ }^{206} \mathrm{~Pb}=0,05903 \pm 0,02 \%$ e $0,000368 \pm 3 \%$; ${ }^{207} \mathrm{~Pb} /{ }^{206} \mathrm{~Pb}=0,91479 \pm 0,01 \%$ e $0,071212 \pm 0,05 \%$ e ${ }^{208} \mathrm{~Pb} / 206 \mathrm{~Pb}=2,1675 \pm 0,01 \%$ e $0,013617 \pm 0,06 \%$, com variação anual de $1 \sigma$. O fator de correção de fracionamento utilizado para normalização é de $0,095 \%$ u.m.a. (unidade de massa atômica). Os resultados foram calculados no programa Isoplot 2003 (Ludwig, 2003) e apresentados com desvios de $2 \sigma$. As constantes utilizadas referem-se as recomendadas por Steiger e Jager (1977): $\lambda\left({ }^{238} \mathrm{U}\right)=1,55125.10^{-10}$ anos $^{-1}$ e $\lambda\left({ }^{235} \mathrm{U}\right)=9,8485.10^{-10}$ $\operatorname{anos}^{-1}$.

A técnica Pb-Pb (EV-TIMS; Kober, 1986) utiliza dois filamentos posicionados frente a frente, sendo um de evaporação (que contém o zircão selecionado) e o outro de ionização, a partir do qual o $\mathrm{Pb}$ é analisado. São realizadas diferentes etapas de evaporação, com aumento gradual de temperatura (step and heat). Os resultados são apresentados com desvios de $2 \sigma$ e as correções de $\mathrm{Pb}$ (comum) são realizadas utilizando-se do modelo de evolução do $\mathrm{Pb}$ proposto por Stacey \& Kramers (1975). Os valores obtidos referem-se a idades aparentes ${ }^{207} \mathrm{~Pb} /{ }^{206} \mathrm{~Pb}$.

ANÁLISES Sm-Nd As análises Sm-Nd foram realizadas em sistema rocha total, segundo os procedimentos descritos em Sato et al. (1995) e Sato (1998). No CPGeo os valores médios medidos para os padrões de $\mathrm{Nd} \mathrm{La}$ Jolla e BCR-1 são: ${ }^{143} \mathrm{Nd} /{ }^{144} \mathrm{Nd}=0,511849 \pm 0,000025$ e $0,512662 \pm 0,000027$, respectivamente (variação anual de $1 \sigma$ ). Erros máximos medidos das razões ${ }^{143} \mathrm{Nd} /{ }^{144} \mathrm{Nd}$ e ${ }^{147} \mathrm{Sm} /{ }^{144} \mathrm{Nd}$ em amostras são menores que $0,004 \%$ e $0,01 \%$, respectivamente, com nível de precisão de $2 \sigma$. As razões isotópicas de $\mathrm{Nd}$ foram obtidas em espectrômetro de massa multi-coletor Finnigan MAT-262, enquanto as de Sm em espectrômetro mono-coletor VG-354. O branco total foi da ordem de $0,4 \eta$ g para o $\mathrm{Nd}$ e $0,7 \eta \mathrm{g}$ para o $\mathrm{Sm}$. Os cálculos de idade modelo foram baseados em valores publicados em De Paolo et al. (1991): ${ }^{143} \mathrm{Nd} /{ }^{144} \mathrm{Nd}=0,7219 \mathrm{e}^{143} \mathrm{Nd} /{ }^{144} \mathrm{Nd}($ CHUR $)=0,512638$, ${ }^{147} \mathrm{Sm} /{ }^{144} \mathrm{Nd}(\mathrm{CHUR})=0,1967 \mathrm{e} \lambda_{147}=6,54.10^{-12} \mathrm{anos}^{-1}$.

ANÁLISES $\mathrm{K}-\mathrm{Ar},{ }^{40} \mathrm{Ar}-{ }^{39} \mathrm{Ar}$ As análises $\mathrm{K}-\mathrm{Ar}$ seguiram os procedimentos discutidos em Amaral et al. 
(1966), com modificações. As análises de K são realizadas em duplicata e quantificadas através de fotometria de chama (aparelho Micronal, modelo B-262). $\mathrm{O}$ argônio é extraído em ultra alto vácuo (pressões inferiores a $10^{-7} \mathrm{~mm}$ de $\mathrm{Hg}$ ) e purificado em fornos de cobre e titânio. A reprodutibilidade do método é da ordem de 2 a $3 \%$, com base na utilização de padrões laboratoriais. Para o cálculo das idades são utilizadas as constantes recomendadas por Steiger e Jager (1978): $\lambda_{\beta}=4,962 \cdot 10^{-10} \operatorname{anos}^{-1} ; \lambda_{\mathrm{k}}=0,581 \cdot 10^{-10-}$ $\operatorname{anos}^{-1} ;\left({ }^{40} \mathrm{Ar}{ }^{36} \mathrm{Ar}\right)=295,5 \mathrm{e}^{40} \mathrm{~K}=0,01167 \% \mathrm{~K}$ total.

$\mathrm{O}$ método ${ }^{{ }^{40}} \mathrm{Ar}^{-39} \mathrm{Ar}$ exige o uso de um reator nuclear IEA-R1: Instituto de Pesquisas Energéticas IPEN-USP, necessário para a ativação neutrônica das amostras, operando em 2 mega-watts. A irradiação das amostras se dá em conjunto com um padrão internacional (Fish Canyon - sanidina) para monitoramento do fluxo de nêutrons, com controle complementar de outros padrões internacionais (GA-1550 - biotita, AC - sanidina, $\mathrm{Hb} 3 \mathrm{gr}$ - hornblenda). O laboratório ${ }^{40} \mathrm{Ar}-$ ${ }^{39} \mathrm{Ar}$ do CPGeo utiliza uma fonte de laser de argônio (480-540ๆm) para extrações em etapa ou por fusão total das amostras irradiadas. Um sistema de extração e purificação de argônio de ultra-alto-vácuo está conectado ao espectrômetro de massa de alta sensibilidade MAP-215-50, totalmente automatizado, controlado por programa do Berkley Geochronological Center, EUA. Detalhes sobre os procedimentos da rotina ${ }^{40} \mathrm{Ar}-{ }^{39} \mathrm{Ar}$ no CPGeo estão reportados em Vasconcelos et al. (2002)

RESULTADOS E DISCUSSÕES Os estudos geocronológicos concentraram-se em três afloramentos (Fig. 2), representados por rochas sienograníticas protomiloníticas (GKM-13: setor central), sienograníticas miloníticas (GKM-75: setor norte) e gnáissicomigmatíticas proto a miloníticas (GKM-7: setor sul).

Os sienogranitos protomiloníticos (porção central do Núcleo Setuva: GKM-13) apresentam, de modo geral, zircões com hábitos prismáticos, formas alongadas, translúcidos a luz transmitida, contendo inclusões (Figs. 8a e 8b). Os dados analíticos U-Pb relativos a quatro frações desses zircões (Tab. 1), quando tratados em diagrama concórdia, distribuíram-se próximos ao intercepto superior, com idade de $2.140 \pm 8 \mathrm{Ma}$ (Fig. 7). Tal valor é interpretado como relativo a época de cristalização desses zircões, caracterizando a formação dessas rochas sienograníticas no Paleoproterozóico. A figura $8 b$ representa uma imagem de zircões desses sienogranitos (GKM-13) obtida através da técnica de catodoluminescência. Interessante notar nesses zircões a tonalidade clara (sugerindo baixos teores em U) e a ausência de sobrecrescimentos metamórficos. Análise pelo método Sm-Nd realizada em rocha total (Tab. 2: GKM-13) apresentou idade modelo $\left(\mathrm{T}_{\mathrm{DM}}\right)$ de $2.95 \mathrm{Ga}$, interpretada como relativa a época de derivação do manto dos precursores crustais desses sienogranitos (fontes arqueanas). $\mathrm{O}$ valor obtido para o $\varepsilon \mathrm{Nd}_{(\mathrm{t})}$, da ordem de -9 (Tab. 2), quando calculado para época de formação desses sienogranitos $(\mathrm{t}=2.100 \mathrm{Ma})$, indica período relativamente longo de residência crus- tal do material envolvido na gênese dessas rochas. Adicionalmente, análises $\mathrm{K}-\mathrm{Ar}$ e ${ }^{40} \mathrm{Ar}-{ }^{39} \mathrm{Ar}$ realizadas em biotitas, desenvolvidas em superfícies Sn de baixo ângulo, da mesma rocha (GKM-13), indicaram idades respectivamente de $586 \pm 15 \mathrm{Ma}$ e $588 \pm 1 \mathrm{Ma}$, similares a obtida por Cordani e Bittencourt (1967) em biotitas de rochas gnáissicas da porção sul do Núcleo Setuva $(587 \pm 17 \mathrm{Ma}, \mathrm{K}-\mathrm{Ar})$. Tais valores sugerem que a colocação desses terrenos a isotermas com temperaturas inferiores à $250-300^{\circ} \mathrm{C}$ ocorreu durante o Neoproterozóico.(Tabs. 3 e 4; Fig. 9).

Outro afloramento estudado refere-se a sienogranitos miloníticos (GKM-75), que ocorrem pouco a norte do anterior (Fig. 2). Os zircões desses sienogranitos denotam, de modo geral, aspecto turvo, cor rosada e riqueza em inclusões e fraturas, sugestivos de processos de metamictização (Fig. 10a). Em imagens de catodoluminescência apresentam núcleos de aspecto brilhante com porções sobrecrescidas de borda, com tonalidades mais escuras (Fig. 10b). Os dados analíticos obtidos (Tab. 1), quando tratados em diagrama concórdia (Fig. 11), se mostram discordantes, sugerindo perdas de chumbo, com idades imprecisas tanto para o intercepto superior (arqueano) como inferior (neoproterozóico). A tendência observada para esses pontos analíticos no diagrama,relativa ao intercepto inferior, tem grande importância, por caracterizar sobrecrescimentos nesses zircões relacionados ao Neoproterozóico, não revelados em zircões dos sienogranitos do setor central do Núcleo Setuva (GKM-13). Adicionalmente, foram realizadas análises em zircões desses sienogranitos miloníticos do setor norte do Núcleo Setuva (GKM-75), utilizando-se da técnica de evaporação de monocristais diretamente em filamento do espectrômetro de massa (EV-TIMS). Revelam uma grande complexidade isotópica, com idades relacionadas ao Arqueano ( 3.000Ma e $\sim 2.640 \mathrm{Ma})$ e ao Paleoproterozóico ( 2.100Ma), figuras 12a e 12b. Acrescente-se que esta técnica é utilizada principalmente na obtenção de idades relacionadas aos núcleos de zircões, não se mostrando favorável em zonas de borda, onde a evaporação é rápida, contando ainda com a presença de quantidade apreciável de $\mathrm{Pb}$ comum (Kober, 1987; Sato et al, 2003). Destaca-se que tal técnica (EV-TIMS) foi utilizada por Sato et al. (2003) em rochas gnáissico-migmatíticas do Complexo Atuba. O padrão isotópico obtido é bastante similar ao aqui observado, com idades em zircões relativas ao Arqueano e ao Paleoproterozóico.

Para as rochas gnáissico-migmatíticas que ocorrem na porção sul do Núcleo Setuva (Fig. 2: afloramento GKM-7) foram realizados estudos U-Pb em níveis francamente ocres (mesossomas), dos níveis leucocráticos intercalados concordantemente com o bandamento (leucossomas), e de veios aplíticos, que se mostram ora concordantes, ora discordantes da estruturação geral. Os zircões existentes nos três litotipos descritos se mostram bastante semelhantes, caracterizados por cristais com hábitos prismáticos, biterminados, formas alongadas, aspecto turvo, normalmente contendo fraturas e inclusões. Em imagens obtidas através de luz transmitida 
Tabela 1: Dados analíticos U-Pb (zircão) :GKM-7:rocha gnáissico-migmatítica do setor sul do Núcleo Setuva (7A:mesossoma; 7B: leucossoma; 7C: veio aplítico) ; GKM-13 : rocha sienogranítica protomilonítica do setor central do Núcleo Setuva e GKM-75 : rocha sienogranítica milonítica do setor norte do Núcleo Setuva.

\begin{tabular}{|c|c|c|c|c|c|c|c|c|}
\hline Amostra & SPU & $\begin{array}{c}\text { Fração } \\
\text { Magnética }\end{array}$ & $\begin{array}{l}\text { Peso } \\
(\mathrm{mg})\end{array}$ & $\mathrm{U}(\mathrm{ppm})$ & $\mathrm{Pb}(\mathrm{ppm})$ & ${ }^{206} \mathrm{~Pb} /{ }^{204} \mathrm{~Pb}$ & ${ }^{207} \mathrm{~Pb} /{ }^{235} \mathrm{U}$ & Erro (\%) \\
\hline GKM-7C & $\begin{array}{l}982 \\
983 \\
984\end{array}$ & $\begin{array}{c}\text { NM(-2) } \\
\text { M(-2) } \\
\text { NM(-1) }\end{array}$ & $\begin{array}{l}0,065358 \\
0,108281 \\
0,131575\end{array}$ & $\begin{array}{c}214,71 \\
251,9 \\
407,21\end{array}$ & $\begin{array}{c}74,674 \\
59,82 \\
75,558\end{array}$ & $\begin{array}{l}332,26 \\
403,13 \\
507,08\end{array}$ & $\begin{array}{l}7,30701 \\
4,55644 \\
3,20058\end{array}$ & $\begin{array}{c}0,721 \\
0,855 \\
1,03\end{array}$ \\
\hline GKM-7B & $\begin{array}{l}978 \\
979 \\
980 \\
981\end{array}$ & $\begin{array}{c}\mathrm{NM}(-3) \\
\mathrm{M}(-3) \\
\mathrm{M}(-2) \\
\mathrm{M}(-1)\end{array}$ & $\begin{array}{c}0,221672 \\
0,335228 \\
0,13999 \\
0,343239\end{array}$ & $\begin{array}{l}126,24 \\
427,72 \\
622,03 \\
562,43\end{array}$ & $\begin{array}{l}34,77 \\
68,71 \\
95,53 \\
70,41\end{array}$ & $\begin{array}{l}512,85 \\
568,67 \\
400,97 \\
344,11\end{array}$ & $\begin{array}{c}6,05361 \\
2,8451 \\
2,52592 \\
1,77886\end{array}$ & $\begin{array}{c}0,851 \\
1,44 \\
1,31 \\
1,06\end{array}$ \\
\hline GKM-7A & $\begin{array}{l}964 \\
965 \\
967\end{array}$ & $\begin{array}{c}\mathrm{NM}(-3) \\
\mathrm{M}(-3) \\
\mathrm{M}(-2)\end{array}$ & $\begin{array}{l}0,127136 \\
0,169965 \\
0,102519\end{array}$ & $\begin{array}{l}132,83 \\
162,68 \\
237,69\end{array}$ & $\begin{array}{c}81,59 \\
90,81 \\
93,4\end{array}$ & $\begin{array}{c}1779,86 \\
1522,8 \\
1742,9\end{array}$ & $\begin{array}{l}17,345 \\
15,428 \\
10,325\end{array}$ & $\begin{array}{c}0,758 \\
1,24 \\
0,999\end{array}$ \\
\hline GKM-13 & $\begin{array}{l}665 \\
666 \\
667 \\
428\end{array}$ & $\begin{array}{c}M(-3) \\
M(-4) a \\
M(-4) b \\
\text { NM(-4) }\end{array}$ & $\begin{array}{l}0,289373 \\
0,239876 \\
0,654806 \\
0,257634\end{array}$ & $\begin{array}{c}175,36 \\
157,13 \\
74,113 \\
136,8\end{array}$ & $\begin{array}{c}76,67 \\
66,283 \\
37,908 \\
52,708\end{array}$ & $\begin{array}{c}833,61 \\
2233,46 \\
293,32 \\
2134,47\end{array}$ & $\begin{array}{l}6,68841 \\
6,77809 \\
6,88092 \\
6,48941\end{array}$ & $\begin{array}{c}1,36 \\
0,943 \\
1,3 \\
1\end{array}$ \\
\hline GKM-75 & $\begin{array}{l}985 \\
986 \\
987\end{array}$ & $\begin{array}{l}M(-1) \\
M(0) \\
M(2)\end{array}$ & $\begin{array}{l}0,043835 \\
0,053174 \\
0,115347\end{array}$ & $\begin{array}{l}478,06 \\
608,31 \\
807,72\end{array}$ & $\begin{array}{c}56,27 \\
78,53 \\
109,45\end{array}$ & $\begin{array}{c}222,12 \\
203,5 \\
213,52\end{array}$ & $\begin{array}{c}0,911419 \\
1,00234 \\
1,08943\end{array}$ & $\begin{array}{c}0,85 \\
0,908 \\
2,04\end{array}$ \\
\hline Amostra & SPU & ${ }^{206} \mathrm{~Pb} /{ }^{238} \mathrm{U}$ & Erro (\%) & ${ }^{207} \mathrm{~Pb} /{ }^{206} \mathrm{~Pb}$ & Erro (\%) & $\begin{array}{l}\text { Idade (Ma) } \\
{ }^{207} \mathrm{~Pb} /{ }^{235} \mathrm{U}\end{array}$ & $\begin{array}{l}\text { Idade }(\mathrm{Ma}) \\
{ }^{206} \mathrm{~Pb} /{ }^{238} \mathrm{U}\end{array}$ & $\begin{array}{l}\text { Idade }(\mathrm{Ma}) \\
{ }^{207} \mathrm{~Pb} /{ }^{206} \mathrm{~Pb}\end{array}$ \\
\hline GKM-7C & $\begin{array}{l}982 \\
983 \\
984\end{array}$ & $\begin{array}{c}0,259133 \\
0,188549 \\
0,15032\end{array}$ & $\begin{array}{c}0,711 \\
0,836 \\
1,02\end{array}$ & $\begin{array}{c}0,20451 \\
0,175267 \\
0,151686\end{array}$ & $\begin{array}{l}0,126 \\
0,168 \\
0,134\end{array}$ & $\begin{array}{l}2149,7 \\
1741,3 \\
1457,3\end{array}$ & $\begin{array}{c}1485,4 \\
1113,5 \\
902,8\end{array}$ & $\begin{array}{l}2862,5 \\
2608,6 \\
2365,0\end{array}$ \\
\hline GKM-7B & $\begin{array}{l}978 \\
979 \\
980 \\
981\end{array}$ & $\begin{array}{l}0,229189 \\
0,139675 \\
0,130479 \\
0,104818\end{array}$ & $\begin{array}{c}0,843 \\
1,44 \\
1,3 \\
1,05\end{array}$ & $\begin{array}{l}0,191566 \\
0,147733 \\
0,140404 \\
0,123085\end{array}$ & $\begin{array}{l}0,122 \\
0,104 \\
0,145 \\
0,125\end{array}$ & $\begin{array}{l}1983,6 \\
1367,5 \\
1279,5 \\
1037,8\end{array}$ & $\begin{array}{c}1330,2 \\
842,8 \\
790,6 \\
642,6\end{array}$ & $\begin{array}{l}2755,7 \\
2319,9 \\
2232,2 \\
2001,4\end{array}$ \\
\hline GKM-7A & $\begin{array}{l}964 \\
965 \\
967\end{array}$ & $\begin{array}{c}0,517484 \\
0,46788 \\
0,337602\end{array}$ & $\begin{array}{c}0,755 \\
1,24 \\
0,997\end{array}$ & $\begin{array}{l}0,243095 \\
0,239153 \\
0,221812\end{array}$ & $\begin{array}{l}0,0702 \\
0,0735 \\
0,0661\end{array}$ & $\begin{array}{l}2954,1 \\
2842,0 \\
2464,3\end{array}$ & $\begin{array}{l}2688,5 \\
2474,3 \\
1875,1\end{array}$ & $\begin{array}{l}3140,3 \\
3144,3 \\
2993,9\end{array}$ \\
\hline GKM-13 & $\begin{array}{l}665 \\
666 \\
667 \\
428\end{array}$ & $\begin{array}{l}0,365326 \\
0,370198 \\
0,375468 \\
0,355078\end{array}$ & $\begin{array}{c}1,36 \\
0,94 \\
1,3 \\
0,933\end{array}$ & $\begin{array}{l}0,132782 \\
0,132792 \\
0,132914 \\
0,131482\end{array}$ & $\begin{array}{c}0,119 \\
0,0747 \\
0,0904 \\
0,25\end{array}$ & $\begin{array}{l}2071,1 \\
2082,9 \\
2096,2 \\
2044,5\end{array}$ & $\begin{array}{l}2007,4 \\
2030,3 \\
2055,1 \\
1958,8\end{array}$ & $\begin{array}{l}2135,1 \\
2135,2 \\
2136,8 \\
2117,8\end{array}$ \\
\hline GKM-75 & $\begin{array}{l}985 \\
986 \\
987\end{array}$ & $\begin{array}{l}0,0893534 \\
0,0932938 \\
0,0962801\end{array}$ & $\begin{array}{c}0,759 \\
0,807 \\
1,95\end{array}$ & $\begin{array}{l}0,0739786 \\
0,0779218 \\
0,0820654\end{array}$ & $\begin{array}{l}0,351 \\
0,397 \\
0,586\end{array}$ & $\begin{array}{l}657,8 \\
705,0 \\
748,2\end{array}$ & $\begin{array}{l}551,7 \\
575,0 \\
592,6\end{array}$ & $\begin{array}{l}1040,9 \\
1144,9 \\
1247,1\end{array}$ \\
\hline
\end{tabular}

e principalmente catodoluminescência de zircões das bandas ocres (mesossoma, Figs. 13a e 13b), observa a presença de uma porção central e sobrecrescimentos com tonalidades mais escuras (mais ricas em $\mathrm{U}$ ) e concêntricas, bem desenvolvidas nas terminações prismáticas. Feições de sobrecrescimento bastante similares de zircões relativos aos níveis leucocráticos (leucossomas), bem como dos veios aplíticos, são descritas por
Kaulfuss (2001). Os dados U-Pb (Tab. 1) relativos a zircões dos mesossomas,quando tratados em diagrama concórdia (Fig. 14a) apresentam dois dos pontos analíticos (M-3 e NM-3) posicionados próximos ao intercepto superior, estando o terceiro (M-1) relativamente afastado. Esses pontos analíticos alinham-se segundo uma discórdia com idades imprecisas de $3190 \pm 12 \mathrm{Ma}$ (intercepto superior) e $570 \pm 45 \mathrm{Ma}$ (intercepto inferior). 
Tabela 2: Dados analiticos Sm-Nd (rocha total).: rocha sienogranitica protomilonitica(GKM-13) e gnáissicomigmatítica(GKM-7A:mesossoma e GKM-7C:veio aplítico) do Núcleo Setuva. $\in$ Nd (t): calculado para $t=$ 2.100Ma (GKM-13) e $t=600 M a(G K M-7 A$ e C).

\begin{tabular}{c|c|c|c|c|c|c|c|c|c|c}
\hline Amostra & $\mathrm{Sm}(\mathrm{ppm})$ & $\mathrm{Nd}(\mathrm{ppm})$ & ${ }^{147} \mathrm{Sm} / 144 \mathrm{Nd}$ & Erro & ${ }^{143} \mathrm{Nd} / 144 \mathrm{Nd}$ & Erro & $\mathrm{f} \mathrm{Sm} / \mathrm{Nd}$ & $\mathrm{T}$ De Paolo $(\mathrm{Ga})$ & $\boldsymbol{\epsilon} \mathrm{Nd}(0)$ & $\boldsymbol{\epsilon} \mathrm{Nd}(\mathrm{t})$ \\
\hline GKM-7C & 3,627 & 24,423 & 0,0898 & 0,0003 & 0,510777 & 0,000016 & $-0,54$ & $2.8 \pm 0.2$ & $-36,3$ & $-28,12$ \\
\hline GKM-7A & 1,082 & 6,869 & 0,0953 & 0,0003 & 0,510836 & 0,000034 & $-0,52$ & $2.9 \pm 0.2$ & $-35,15$ & $-27,39$ \\
\hline GKM-13 & 20,568 & 132,607 & 0,0938 & 0,0003 & 0,510747 & 0,000012 & $-0,52$ & $2.95 \pm 0.2$ & $-36,89$ & $-9,32$ \\
\hline
\end{tabular}

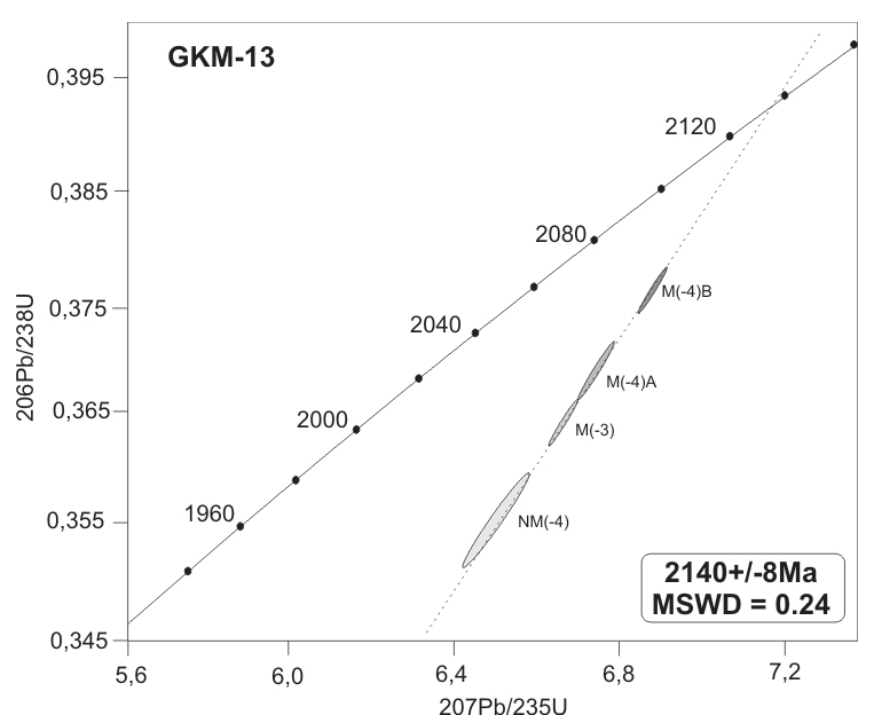

Figura 7: Diagrama U-Pb em zircões (Concórdia) do sienogranito protomilonítico (porção central do Núcleo Setuva:GKM-13).

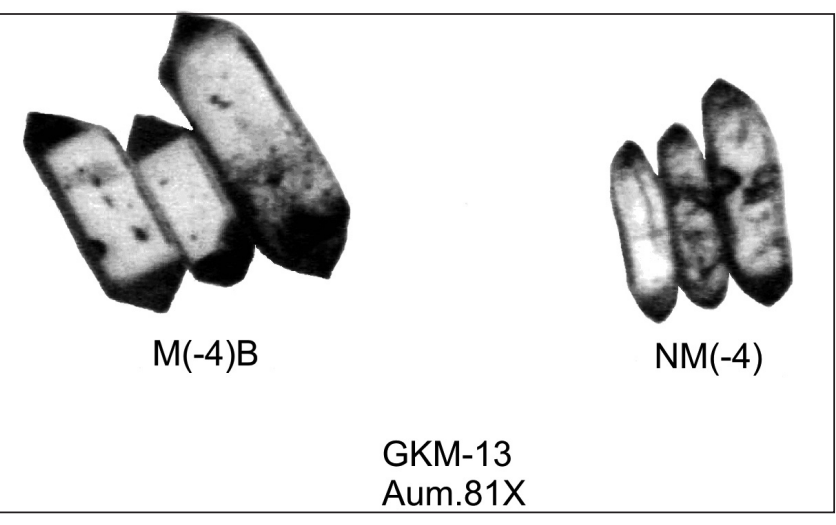

Figura 8a: Imagem em luz transmitida de zircões do sienogranito protomilonítico GKM-13(zircões com hábitos prismáticos, formas alongadas, translúcidos, contendo inclusões).

Os dados relativos aos zircões dos leucossomas (Fig. 14b) e veios aplíticos (Fig. 14c) apresentam os pontos analíticos distribuídos relativamente mais próximos ao

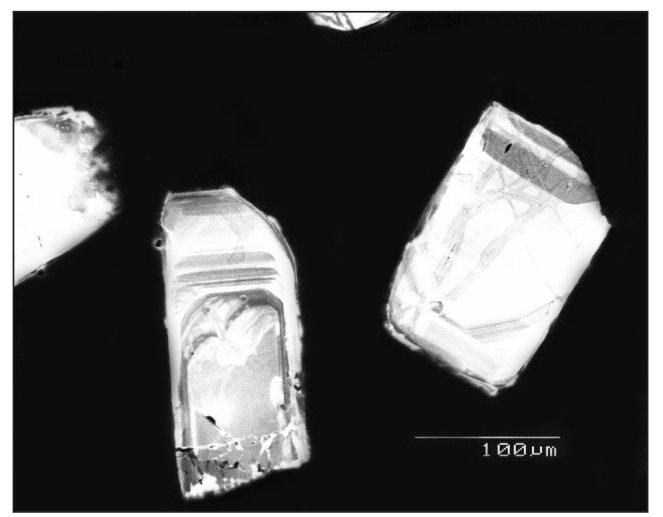

Figura 8b: Imagem de catodoluminescência de zircões do sienogranito protomilonítico GKM-13 (tonalidade clara e ausência de sobrecrescimentos metamórficos).

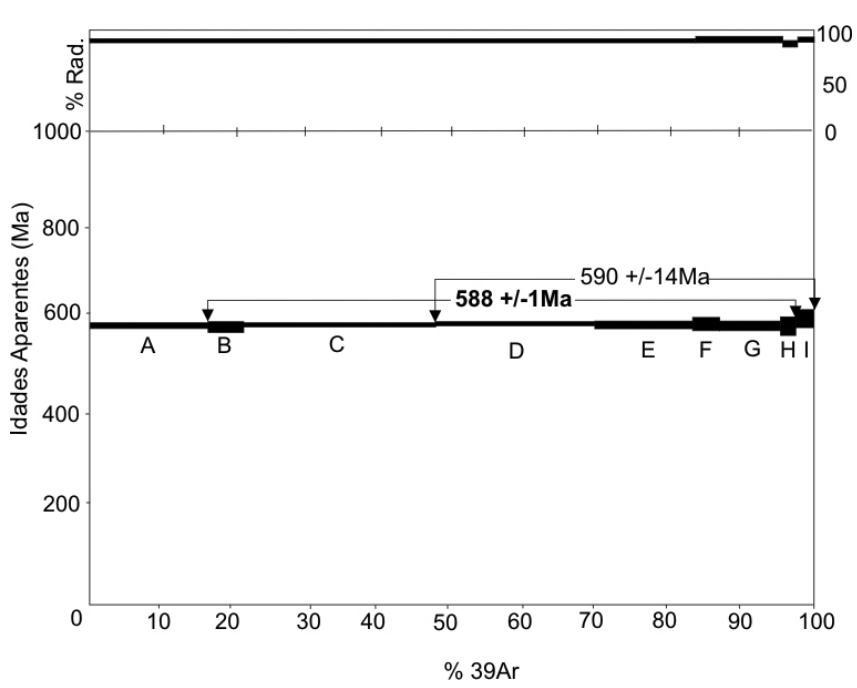

Figura 9: Diagrama ${ }^{40} \mathrm{Ar}-{ }^{39} \mathrm{Ar}$, em biotita ,do sienogranito protomilonítico (porção central do Núcleo Setuva:GKM-13).

intercepto inferior do diagrama concórdia. As idades obtidas são bastante imprecisas, da ordem de 3200$3000 \mathrm{Ma}$ para o intercepto superior e 500-600Ma para 
Tabela 3: Dados analíticos $K-A r$ (biotita) da rocha sienogranítica protomilonítica do setor central do Núcleo Setuva ( GKM-13).

\begin{tabular}{|c|c|c|c|c|c|c|c|c|c|}
\hline Amostra & SPK & Mineral & $\%$ de $\mathrm{K}$ & $\begin{array}{c}\text { ERRO } \\
(\%)\end{array}$ & $\begin{array}{c}{ }^{40} \mathrm{ArRad} \\
\text { cc STP }\left(10^{-6}\right)\end{array}$ & $\begin{array}{c}{ }^{40} \mathrm{Ar} \mathrm{Atm} \\
(\%)\end{array}$ & $\begin{array}{c}\text { T(Max.) } \\
\text { Ma }\end{array}$ & IDADE & $\begin{array}{l}\text { ERRO Max. } \\
\text { (Ma) }\end{array}$ \\
\hline GKM-13 & 7763 & Biotita & 4,8046 & 1,3688 & 129,9 & 4,15 & 602 & 586,4 & 15,5 \\
\hline
\end{tabular}

Tabela 4: Dados analíticos ${ }^{40} \mathrm{Ar}-{ }^{39} \mathrm{Ar}$ (biotita) da rocha sienogranítica protomilonitica do setor central do Núcleo Setuva (GKM-13).

\begin{tabular}{c|c|c|c|c|c|c|c|c|c|c}
\hline $\mathrm{N}^{\mathrm{o}} \mathrm{Lab}$. & $\begin{array}{c}\mathrm{Laser} \\
(\mathrm{W})\end{array}$ & ${ }^{40} \mathrm{Ar}{ }^{\beta 9} \mathrm{Ar}$ & ${ }^{38} \mathrm{Ar}{ }^{39} \mathrm{Ar}$ & ${ }^{37} \mathrm{Ar}{ }^{39} \mathrm{Ar}$ & ${ }^{36} \mathrm{Ar} /{ }^{39} \mathrm{Ar}$ & ${ }^{40 *} \mathrm{Ar} /{ }^{39} \mathrm{Ar}$ & $\% \mathrm{Rad}$ & $\begin{array}{c}{ }^{40} \mathrm{Ar} \\
(\mathrm{mols})\end{array}$ & $\begin{array}{c}\mathrm{Idade} \\
(\mathrm{Ma})\end{array}$ & $\begin{array}{c} \pm \\
(\mathrm{Ma})\end{array}$ \\
\hline 0303-01 A & 0,10 & 81,76132 & 0,01428 & 0,00000 & 0,00324 & 80,80396 & 98,8 & $1,90 \mathrm{E}-14$ & 574,42 & 2,56 \\
\hline 0303-01 B & 0,16 & 82,10786 & 0,01017 & 0,00000 & 0,00087 & 81,84872 & 99,7 & $5,83 \mathrm{E}-15$ & 580,77 & 4,50 \\
\hline $0303-01 \mathrm{C}$ & 0,24 & 83,11975 & 0,01252 & 0,01658 & 0,00145 & 82,69514 & 99,5 & $3,07 \mathrm{E}-14$ & 585,90 & 1,93 \\
\hline $0303-01 \mathrm{D}$ & 0,32 & 83,39194 & 0,01167 & 0,00000 & 0,00122 & 83,03142 & 99,6 & $2,62 \mathrm{E}-14$ & 587,93 & 1,91 \\
\hline $0303-01 \mathrm{E}$ & 0,40 & 83,86861 & 0,01137 & 0,06341 & 0,00165 & 83,39433 & 99,4 & $1,61 \mathrm{E}-14$ & 590,13 & 2,92 \\
\hline $0303-01 \mathrm{~F}$ & 0,48 & 83,63321 & 0,01060 & 0,04973 & $-0,00105$ & 83,95339 & 100,4 & $4,27 \mathrm{E}-15$ & 593,50 & 6,47 \\
\hline $0303-01 \mathrm{G}$ & 0,56 & 83,47356 & 0,01167 & 0,02993 & $-0,00056$ & 83,64410 & 100,2 & $9,82 \mathrm{E}-15$ & 591,63 & 3,65 \\
\hline $0303-01 \mathrm{H}$ & 0,75 & 84,67618 & 0,01536 & 0,02561 & 0,00472 & 83,28702 & 98,4 & $2,69 \mathrm{E}-15$ & 589,48 & 8,03 \\
\hline $0303-01 \mathrm{I}$ & 1,50 & 84,59439 & 0,00774 & 0,21380 & $-0,00607$ & 86,43108 & 102,1 & $2,67 \mathrm{E}-15$ & 608,36 & 8,42 \\
\hline
\end{tabular}

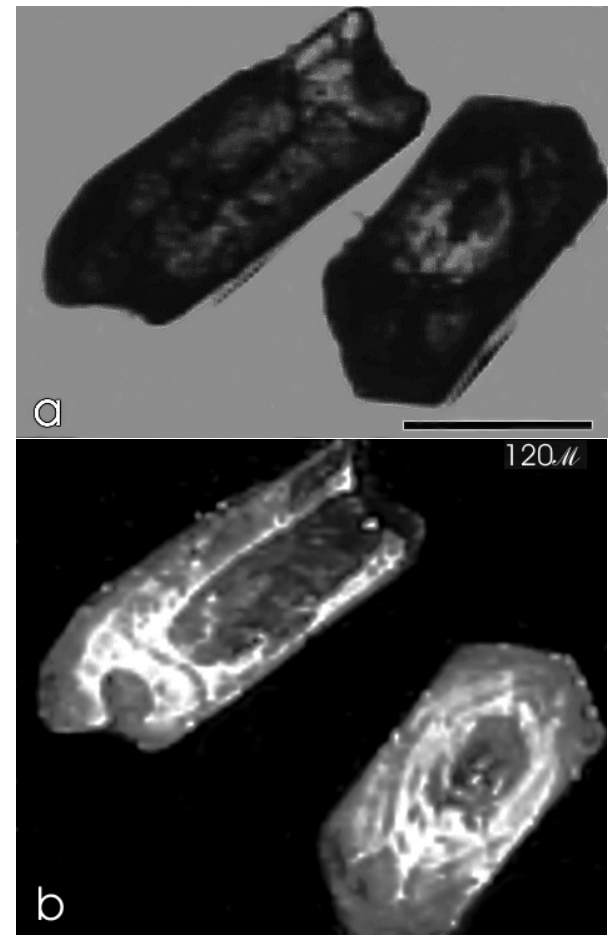

Figura 10 a,b: Imagens em luz transmitida. a) zircões de aspecto turvo, rico em inclusões e fraturas) e catodoluminescência. b) núcleos e porções sobrecrescidas de borda). Sienogranito milonítico(porção norte do Núcleo Setuva: GKM-75). o intercepto inferior. Embora as idades sejam relativamente imprecisas, observa-se nos alinhamentos obtidos (Figs. $14 \mathrm{~A}, \mathrm{~B}$ e C), um posicionamento dos dados analíticos relativos aos zircões dos mesossomas mais próximos ao intercepto superior e dos leucossomas e veios aplíticos mais próximos ao intercepto inferior da curva concórdia, sugerindo processos de migmatização de terrenos antigos (arqueanos) no final do Pré-Cambriano.

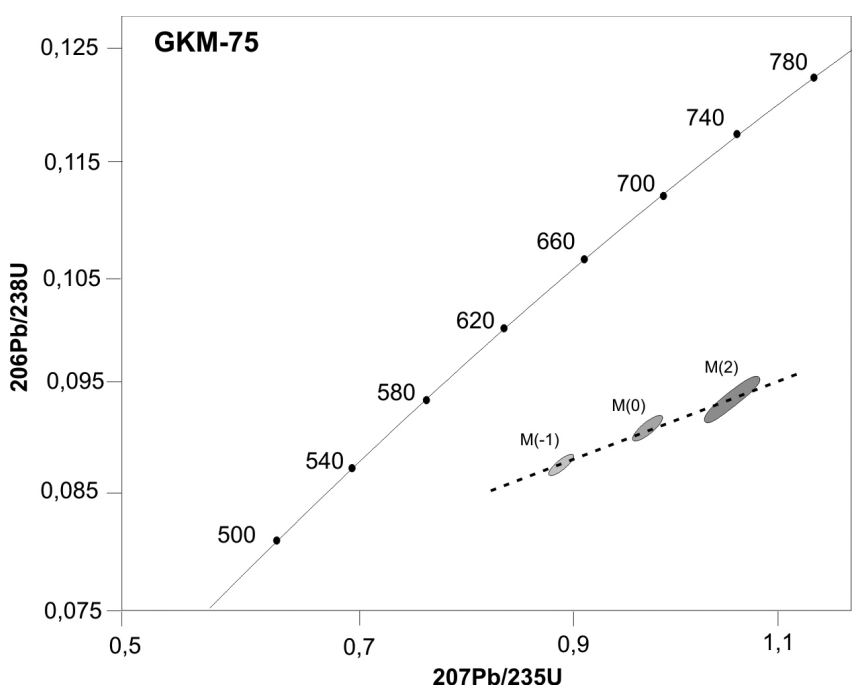

Figura 11: Diagrama U-Pb em zircões (Concórdia) do sienogranito milonítico (porção norte do Núcleo Setuva:GKM-75). 


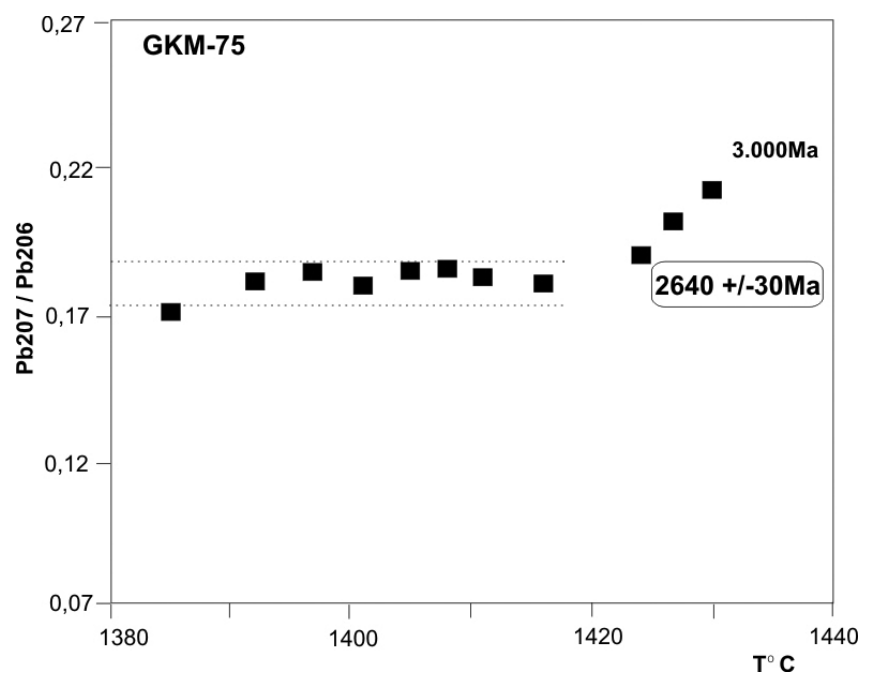

Figura 12a: Diagrama $\mathrm{Pb}^{207} / \mathrm{Pb}^{206}$ versus temperatura (step and heating),em zircão do sienogranito milonítico da porção norte do Núcleo Setuva: GKM-75(1).

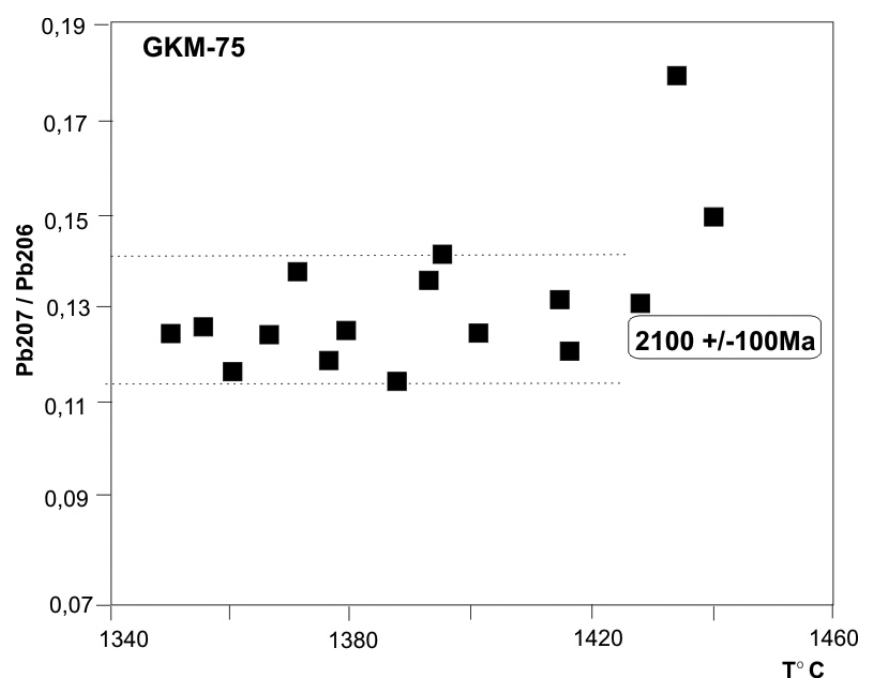

Figura 12b: Diagrama $\mathrm{Pb}^{207} / \mathrm{Pb}^{206}$ versus temperatura (step and heating),em zircão do sienogranito milonítico da porção norte do Núcleo Setuva: GKM-75(2).

Análises adicionais foram realizadas em zircões dos mesossomas, utilizando-se da técnica de evaporação de monocristais diretamente em filamento do espectrômetro de massa. Acusaram idades (platôs) entre de 3.150-3.100Ma (Figs. 15a e 15b), relativamente próximas a observada para o intercepto superior do diagrama concórdia $(3.190 \pm 12 \mathrm{Ma})$. As idades modelo $\left(\mathrm{T}_{\mathrm{DM}}\right)$ obtidas pelo método Sm-Nd, tanto em mesossomas como em veios aplíticos, aproximam-se de $3,0 \pm 0,2 \mathrm{Ga}$, com valores de $\varepsilon \mathrm{Nd}_{(\mathrm{t})}$ extremamente negativos (-27/-28), quando calculados para o Neoproterozóico (Tab. 2), caracterizando um longo período de residência crustal do material envolvido na formação dessas rochas gnáissico-migmatíticas.

CONSIDERAÇÕES FINAIS O estudo geológico-geocronológico dos terrenos pertencen-

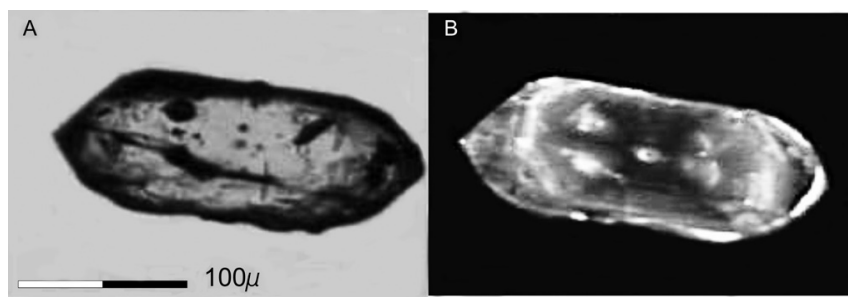

Figura 13: Imagens de zircões do mesossoma da rocha gnáissico-migmatítica da porção sul do Núcleo Setuva: GKM-7 (A-luz transmitida; B-catodoluminescência). Zircões prismáticos:presença de uma porção central e sobrecrecimentos com tonalidades mais escuras.

tes ao Núcleo Setuva revela um quadro tectônico complexo, de evolução policíclica, envolvendo tanto os litotipos graníticos (setor centro-norte), bem como gnáissico-migmatíticos (setor sul). As observações realizadas em zircões dessas rochas, utilizando-se de imagens obtidas através de técnicas de catodoluminescência e luz transmitida foram de grande importância, contribuindo significativamente ao estabelecimento deste cenário tectônico. Tais imagens revelam a predominância de zircões zonados, onde se destaca uma porção de núcleo e bordas de sobrecrescimento, heterogeneamente desenvolvidas, com diferentes formas e dimensões. Refletem heranças isotópicas (núcleos), bem como sobrecrescimentos posteriores (zonas de borda), que permitem recuperar importantes informações relativas a evolução geológica dessas rochas. Em zircões dessa natureza, a utilização da metodologia U-Pb convencional( TIMS) é prejudicada, e nem sempre fornece idades precisas, notadamente de zonas internas dos cristais, razão pela qual foram realizados estudos adicionais através da técnica de evaporação de monocristal diretamente em filamento do espectrômetro de massa (EV-TIMS).

Autilização conjunta dessas técnicas permitiu reconhecer em terrenos gnáissico-migmatíticos (setor sul) do Núcleo Setuva, idades arqueanas (3.200-3.000Ma) e em sienogranitos miloníticos (setor norte), idades do Arqueano tardio ( 2.650Ma) e Paleoproterozóico ( 2.100Ma ). Esses valores, embora imprecisos, referem-se a idades de núcleos de zircões, obtidas no intercepto superior de diagramas concórdia, onde os pontos analíticos encontram-se relativamente afastados. Tais pontos analíticos distribuem-se mais próximos ao intercepto inferior dos diagramas, com idades também imprecisas, sem significado geológico,mas relacionadas ao final do Neoproterozóico. Distinguem-se desse padrão isotópico os zircões relativos aos sienogranitos protomiloníticos da porção central do Núcleo Setuva, que não revelam sobrecrescimentos (relacionados ao final do Neoproterozóico) e cujos dados analíticos posicionam-se próximos ao intercepto superior do diagrama concórdia, indicando para essas rochas idade de formação paleoproterozóica (2.140 $\pm 8 \mathrm{Ma})$. Neste caso, a tectônica neoproterozóica só foi caracterizada através das metodologias $\mathrm{K}-\mathrm{Ar} /{ }^{40} \mathrm{Ar}-{ }^{39} \mathrm{Ar}$ em biotitas ( 590Ma), 


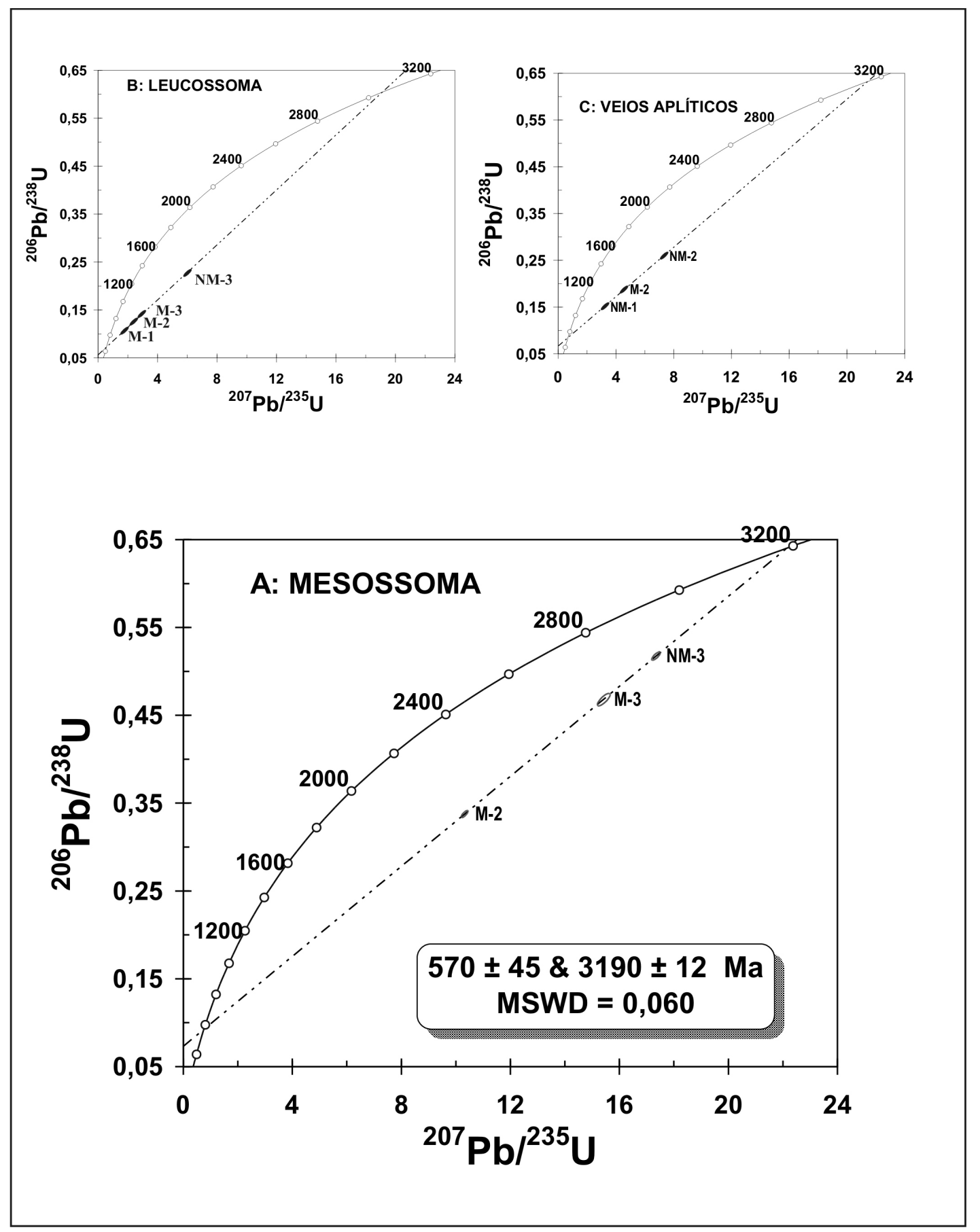

Figura 14: Diagrama U-Pb em zircões (Concórdia) de rocha gnáissico migmatítica da porção sul do Núcleo Setuva: GKM-7 (A: mesossoma; B: leucossoma; C: veios aplíticos).

sugerindo tal época como relativa a colocação dessas rochas a temperaturas inferiores a $300^{\circ}-250^{\circ} \mathrm{C}$.

Oquadroisotópicoapresentadosemostracoerente com o padrão estrutural, relacionado a uma tectônica controlada, em grande parte, por cisalhamentos. Referese a uma tectônica inicial de baixo a médio ângulo (cavalgamentos) associada a cisalhamentos transcorrentes e dobramentos tardios (Fiori et al., 1987a; Fiori, 1990). Essa tectônica parece ser a responsável pelo fatiamento, aloctonia e colocação lado a lado de terrenos oriundos de diferentes níveis crustais durante o Neoproterozóico.
Em termos regionais o quadro geológico-geocronológico apresentado se mostra bastante similar ao observado para os terrenos pertencentes ao Complexo Atuba. Este inclui rochas gnáissico-migmatíticas, com heranças em zircões relativas ao Arqueano (3.100-2.900Ma; 2.700-2.600Ma) e Paleoproterozóico (2.200-2.100Ma). As idades modelo Sm-Nd (Tdm) distribuem-se, similarmente ao observado para as rochas do Núcleo Setuva, entre 3,1 e 2,8Ga. As rochas pertencentes ao Complexo Atuba se apresentam intensamente retrabalhadas, migmatizadas durante o Neoproterozói- 


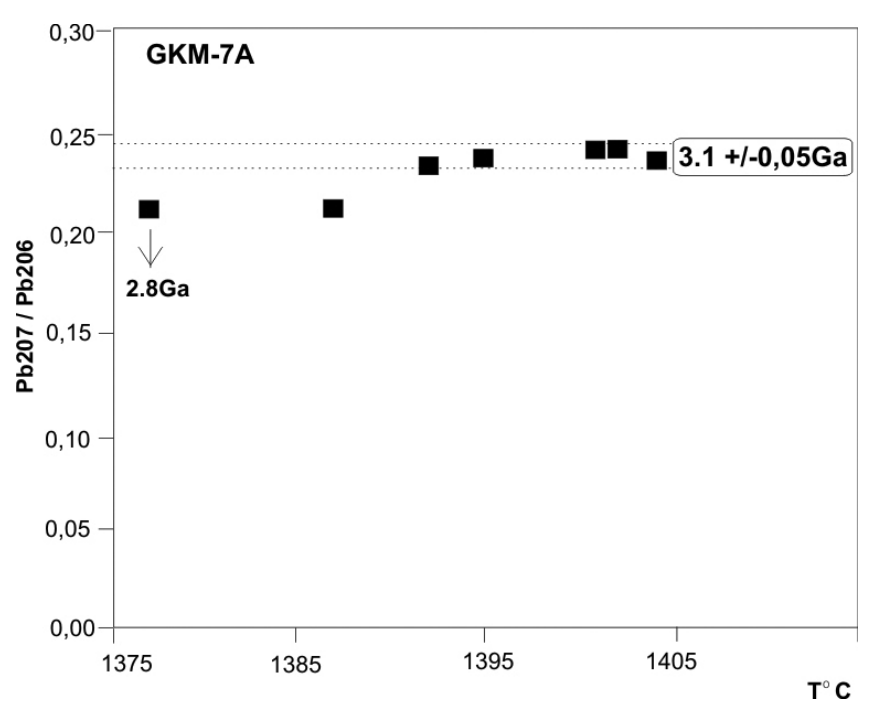

Figura 15a: Diagrama ${ }^{207} \mathrm{~Pb} /{ }^{206} \mathrm{~Pb}$ versus temperatura (step and heating): zircão do mesossoma da rocha gnáissico-migmatítica da porção sul do Núcleo SetuvaGKM-7A.

co ( 600Ma), conforme idades U-Pb (intercepto inferior) obtidas em zonas de sobrecrescimento de zircões e valores K-Ar e ${ }^{40} \mathrm{Ar}^{39} \mathrm{Ar}$ em anfibólios e biotitas (Siga Jr. et al., 1995; Kaulfuss, 2001 e Sato et al., 2001). Distintamente, os Núcleos Betara e Tigre, posicionados a norte da Zona de Cisalhamento Lancinha, são constituídos essencialmente de rochas graníticas proto a miloníticas, com idades U-Pb (zircão) do Paleoprote-

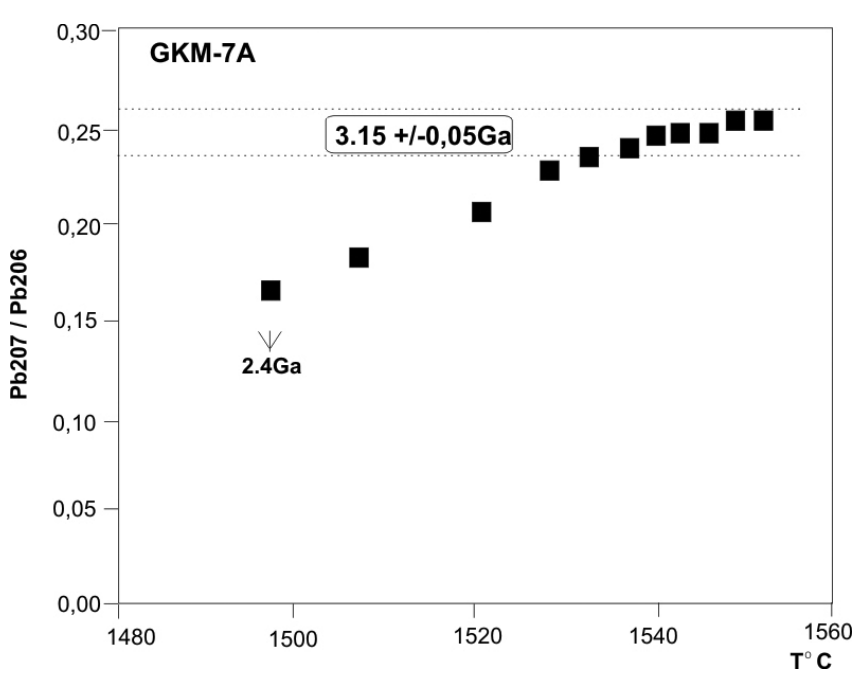

Figura 15b: Diagrama ${ }^{207} \mathrm{~Pb} /{ }^{206} \mathrm{~Pb}$ versus temperatura (step and heating): zircão do mesossoma da rocha gnáissico migmatítica da porção sul do Núcleo Setuva- GKM-7A.

rozóico, com predominância de termos sienograníticos com idades do final do Paleoproterozóico, em torno de 1.750Ma, relacionadas a Tafrogênese Estateriana (Brito Neves et al. 1995, Kaulfuss 2001 e Cury et al. 2002). Agradecimentos Os autores agradecem aos revisores da revista $(\mathrm{RBG})$ e à FAPESP, através dos processos 06/03608-6 e 05/58688-1.

\section{Referências}

Almeida F.F.M., Amaral G., Cordani U.G., Kawashita K. 1973. The Precambrian evolution of Soth America cratonic margin, south of the Amazon River. In: A.E.M. Nirn \& F.G. Stheli (Eds.). The ocean basins and margins. New York, Plenum Press, 1, p. 411-446.

Althoff F.J. \& Fiori A.P. 1991. Estruturas macro, meso e microscópicas da porção ocidental da Antiforma do Setuva - PR. Boletim Paranaense de Geociências, 39:51-64.

Amaral G., Cordani U.G., Kawashita K., Reynolds J.H. 1966. Potassium-Argon dates of basaltic rocks from southern Brazil. Geochimica et Cosmochimica Acta, 30(2):159189.

Basei M.A.S., Siga Jr. O., Machiavelli A., Mancini F. 1992. Evolução tectônica dos terrenos entre os Cinturões Ribeira e Dom Feliciano (PR - SC). Revista Brasileira de Geociências, 22:216-221.

Basei M.A.S., Siga Jr. O., Sato K., Sproesser W.M. 1995. A metodologia Urânio-Chumbo na Universidade de São Paulo: Princípios, aplicações e resultados obtidos. Anais da Academia Brasileira de Ciências, 67(2):221-237.

Batola Jr. F.J., Ferreira da Silva A.T.S., Algarte J.P. 1981. O Pré-Cambriano da região sul-sudeste do Estado de São Paulo e este-nordeste do Estado do Paraná. In: SBG, Simpósio Regional de Geologia do Sudeste, 3. Anais, p. 94-108.
Bigarella J.J. \& Salamuni R. 1956. Estudos preliminares na Série Açungui: algumas estruturas singenéticas nos dolomitos da Formação Capiru. Bol. Arq. Biol. Tecn., 1: 11-197.

Bigarella J.J. \& Salamuni R. 1967. Geologia do Pré-Devoniano e intrusivas subseqüentes da porção oriental do Estado do Paraná. Boletim Paranaense de Geociências, 23-25:347.

Biondi J. C. 1983. Mapa geológico da área do embasamento do Estado do Paraná. Curitiba, MINEROPAR, escala $1: 250.000$.

Biondi J.C., Cava L.T., Soares P.C., 1989. Mapa Geológico do Estado do Paraná. Brasília, MME/DNPM/MINEROPAR, escala 1:650.000.

Brito Neves B.B., Sá J.M., Nilson A.A., Botelho N.F. 1995. A tafrogênese Estateriana nos blocos Paleoproterozóicos da América do Sul e processos subseqüentes. Geonomos, 3:1-21.

Campanha G.A. da C. 1991. Tectônica proterozóica no alto e médio Vale do Ribeira, estados de São Paulo e Paraná. São Paulo, Tese de Doutoramento, Instituto de Geociências, Universidade de São Paulo, 296 p.

Campanha G.A., Bistrichi C.A., Almeida M.A. 1987. Considerações sobre a organização litoestratigráfica e evolução tectônica da Faixa de Dobramentos Apiaí. In: SBG, 
Simpósio Sul-Brasileiro de Geologia, 3, Anais, p. 725742.

Carvalho P.F. \& Pinto E.A. 1937. Reconhecimento geológico na Série Açungui. Rio de Janeiro, DNPM, Boletim 71, $29 \mathrm{p}$.

Chiodi Filho C. 1984. Contribuição à geologia das regiões sul paulista e leste paranaense, grupos Açungui e Setuva. In: SBG, Congresso Brasileiro de Geologia, 33, Anais, p. 2394-2406.

Cordani U.G. \& Bittencourt I. 1967. Determinações de idade Potássio - Argônio em rochas do Grupo Açungui. In: SBG, Congresso Brasileiro de Geologia, 21, Anais, 1, p. 218-233.

Cury L.F., Kaulfuss G.A., Siga Jr O., Basei M.A.S., Harara O.M.M., Sato K. 2002. Idades U-Pb (zircões) de 1.75Ga em granitóides alcalinos deformados dos núcleos Betara e Tigre: Evidências de regimes extensionais do Estateriano na Faixa Apiaí. Geologia USP: Série Cientifica, 2:95-108.

Daitx E. C. 1996. Origem e evolução dos depósitos sulfetados tipo-perau (Pb-Zn-Ag), com base nas jazidas $\mathrm{Ca}$ noas e Perau (Vale do Ribeira, PR). Rio Claro, Tese de Doutoramento. Instituto de Geociências, UNESP, 435p.

De Paolo D.J., Linn A.M., Chubbert G. 1991. The continental age distribution: methods of determining mantle separation ages from $\mathrm{Sm}-\mathrm{Nd}$ isotopic data and application to the southwestern Unite States. Journal of Geophisical Research, 96:2071-2088.

Derby O. 1878. Geologia da região diamantifera da Província do Paraná, Brasil. Rio de Janeiro, Arch. Musc. Nac., Boletim 3, p.86-89.

Ebert H. 1971. Observações sobre as litologias e subdivisão do Grupo Setuva no estado do Paraná, com sugestões à tectônica geral do geossinclínio Açungui. In: SBG, Congresso Brasileiro de Geologia, 25, Anais, p.131-165.

Fassbinder E. 1990. Análise Estrutural da Falha da Lancinha, Estado do Paraná Dissertação de Mestrado, Instituto de Geociências, Universidade de São Paulo, 165p.

Fassbinder E. 1996. A unidade Água Clara no contexto do Grupo Açungui: um modelo transpressivo de colisão oblíqua no Neoproterozóico paranaense. São Paulo, Tese de Doutoramento, Instituto de Geociências, Universidade de São Paulo, 207p.

Fiori A.P. 1990. Tectônica e estratigrafia do Grupo Açungui a norte de Curitiba. São Paulo, Tese de Livre Docência, Instituto de Geociências, Universidade de São Paulo, $261 p$.

Fiori A.P. 1991. Tectônica de cavalgamento no Grupo Açungui. In: SBG, Simpósio Nacional de Estudos Tectônicos, 3, Atas, p. 134-136.

Fiori A.P., Fassbinder E., Gois J.R., Fumagalli C.E. 1987a. Compartimentação tectônica do Grupo Açungui a norte de Curitiba. In: SBG, Simpósio Sul Brasileiro de Geologia, 3, Atas, 183-196.

Fiori A.P., Salamuni E., Fassbinder E. 1987b. Geologia da região de Bateias - Bocaiuva do Sul. In: SBG, Simpósio Sul Brasileiro de Geologia, 3, Atas, p. 773-787.

Fiori A.P., Fumagalli C.E., Gois J.R., Salamuni E. 1987c. As principais estruturas dobradas do Grupo Açungui na região de Rio Branco - Bocaiúva do Sul. In: SBG, Simpó- sio Sul Brasileiro de Geologia, 3. Atas, p. 281-301.

Fiori A.P., Fassbinder E., Salamuni E. 2003. Evolução geológica do Grupo Açungui. In: SBG, Simpósio de Geologia do Sudeste, 8, Atas, p.16.

Fritzons Jr. O., Piekarz G.F., Falcade D. 1982. Geologia e potencial econômico do Grupo Setuva (PR). In: Congresso Brasileiro de Geologia, 32. Anais, p. 991-1001.

Hasui Y., Carneiro C.D.R., Coimbra A.M. 1975. The Ribeira Folded Belt. Revista Brasileira de Geociências, 5:257266.

Hasui Y., Ebert H.D., Quade H. 1984. Aspectos geológicos da megantiforme da Serra do Cadeado (PR). In: SBG, Congresso Brasileiro de Geologia, 33, Anais, p. 23802393.

Kaefer L.Q. \& Algarte J.P. 1972. Projeto Sudeste de São Paulo, Folha Itararé SG-22-X-B, DNPM-CPRM, Relatório Interno, 162p.

Kaulfuss G.A. 2001. Geocronologia dos Núcleos de Embasamento Setuva, Betara e Tigre, Norte de Curitiba- PR. São Paulo, Dissertação de Mestrado, Instituto de Geociências, Universidade de São Paulo, 115p.

Kober B. 1986. Whole-grain evaporation for ${ }^{207} \mathrm{~Pb}^{206} \mathrm{~Pb}$ age investigations on single zircons using a double-filament source. Contributions to Mineralogy and Petrology, 93:482-490.

Krogh T.E. 1973. A low contamination method for hydrothermal decomposition of zircon and extraction of $U$ and $\mathrm{Pb}$ for isotopic age determinations. Geochimica et Cosmochimica Acta, 37:485-494.

Krogh T.E. 1982. Improved accuracy of U-Pb zircon ages by the creation of more concordant systems using an air abrasion technique. Geochimica et Cosmochimica Acta, 46:637-649.

Ludwig K.R. 2003. User's manual for Isoplot 3.0: a geochronological toolkit for Microsoft Excel. Berkeley Geochronology Center, Special Publication, vol.4, 71p.

Maack R. 1947. Breves notícias sobre a geologia dos estados do Paraná e Santa Catarina. Arquivos de Biologia e Tecnologia, 2:63-154.

Marini O.J. 1970. Geologia da Folha de Rio Branco do Sul. Rio Claro, Tese de Doutoramento, Faculdade de Filosofia Ciências e Letras, UNESP, 190 p.

Marini O.J., Trein E., Fuck R.A. 1967. O Grupo Açungui no estado do Paraná. Boletim Paranaense de Geociências, Série Especial, 23:43-104.

Martin M.A.B., Monteiro L.V.S., Campos Neto M.C., Juliani C. 1994. Petrografia dos metadioritos-metagabros do Núcleo Betara - PR. In: SBG, Congresso Brasileiro de Geologia, 38, Anais, p.99-100.

Oliveira E.P. 1927. Geologia dos recursos minerais do estado do Paraná. Serviço Geológico e Mineralógico do Rio de Janeiro, Monografia 6, 172p.

Oliveira A.I. \& Leonardos O.H. 1943. Geologia do Brasil. Ministério da Agricultura, Rio de Janeiro, 782p.

Parrish R.R. 1987. An improved micro-capsule for zircon dissolution in U-Pb geochronology. Isotope Geosciences, 66:99-102.

Piekarz G.F. 1981. Reconhecimento das Unidades correlacionáveis à seqüência mineralizada do Perau - Estado do Paraná. In: SBG, Simpósio Regional de Geologia, 3, 
Atas, p. 148-154.

Piekarz G.F. 1984. Geologia e resultados preliminares de pesquisa mineral do Núcleo Betara da Formação Perau. In: SBG, Congresso Brasileiro de Geologia, 33, Anais, p.3682-3696.

Popp J.H., Angulo R., Bigarella J.J. 1979. Geologia da Região Metropolitana de Curitiba, Recursos Naturais. Folha de Ouro Fino. Curitiba, COMEC, Boletim, 30p.

Reis Neto J. \& Soares P.C. 1987. Um estudo de caracterização termo-dinâmica de micro-estruturas dos Grupos Açungui e Setuva (PR). In: SBG, Simpósio Sul-Brasileiro de Geologia, 3, Atas. Curitiba, p.147-165.

Reis Neto J.M. 1994. Faixa Itaiacoca: registro de uma colisão entre dois blocos continentais no neoproterozóico. São Paulo, Tese de Doutoramento, Instituto de Geociências, USP, 253p.

Salamuni E. 1991. Análise Estrutural do Núcleo Betara, Rio Branco do Sul - PR.. Rio Claro, Dissertação de Mestrado, UNESP, 147p.

Salamuni E., Fiori A.P., Wernick E. 1993. Características estruturais e evolução tectônica do Núcleo Betara a norte de Curitiba (PR). Boletim Paranaense de Geociências, 41:91-127.

Sato K. 1998. Evolução crustal da Plataforma Sul Americana com base na geoquímica isotópica $\mathrm{Sm}-\mathrm{Nd}$. São Paulo, Tese de Doutoramento, Instituto de Geociências, Universidade de São Paulo, 299p.

Sato K., Tassinari C.C.G., Kawashita K., Petronilho L. 1995. $\mathrm{O}$ método geocronológico $\mathrm{Sm}-\mathrm{Nd}$ no IGc-USP e suas aplicações. Anais da Academia Brasileira de Ciências, 67(3):315-336.

Sato K., Nutman A.P., Siga Jr O., Basei M.A.S., Spröesser W.M. 2001. Meso-Archean orthogneiss in the Atuba Complex in a Neoproterozoic Brasiliano mobile belt in SE Brazil: An integrate IDTIMS, EVTIMS and SHRIMP zircon dating study. Gondwana Research, 4(4):775-777.

Sato K., Siga Jr. O., Nutman A.P., Basei M.A.S., Mcreath I., Kaulfuss G.A. 2003. The Atuba Complex, southern South American Platform: Archean components and Pleoproterozoic to Neoproterozoic tectonothermal events. Gondwana Research, 6(2):251-263.

Schöll W.U., Lopes O.M., Silva A.C.G.A., Prozzi C.R. 1980. Geologia do Pré-Cambriano do Anticlinal do Setuva (Município de Bocaiúva do Sul e Rio Branco do sul -
PR). In: SBG, Congresso Brasileiro de Geologia, 31, Anais, p. 3003-3012.

Siga Jr. O., Basei M.A.S., Reis Neto J.M., Machiavelli A., Harara O.M. 1995. O Complexo Atuba: um cinturão Paleoproterozóico intensamente retrabalhado no Neoproterozóico. Revista Geologia-USP, Série Científica, 26:69-98.

Silva P.C.S., Vasconcellos C.V.S., Yamato A.A., Vasconcelos A.A. 1998a. Projeto Folha Curitiba (SG22-X-D-I). São Paulo, CPRM/DNPM, Relatório Final, 91p.

Silva P.C.S., Vasconcellos C.V.S., Yamato A.A., Pedreira A.J. 1998b. O Grupo Açungui na Folha Curitiba (SG22X-D-I). In: SBG, Congresso Brasileiro de Geologia, 40, Anais, p. 40.

Soares, P.C. 1987. Seqüências tectono-sedimentares e tectônica deformadora no centro-oeste do escudo paranaense. In: SBG, Simpósio Sul-Brasileiro de Geologia, 3. Atas, p.743-771.

Stacey J.S., Kramers D. 1975. Aproximation of terrestrial lead isotope evolution by a two stage model. Earth and Planetary Science Letters, 26:207-221.

Steiger R.H. \& Jager E. 1977. Subcomission on geochronology: convention on the use of decay constants in geo and cosmochronology. Earth Planetary Science Letters, 36: 359-362.

Takahashi A.T., Chiodi Filho C., Silva C.R., Batolla Jr. F. 1981. Projeto integração e detalhe geológico no Vale do Ribeira. Área Ribeirão do Perau. São Paulo, DNPM/ CPRM, Relatório Interno, 94p.

Teixeira W. 1982. Estudo geocronológico das folhas SG-21 Assunción e SG-22 Curitiba. Projeto RADAMBRASIL, Relatório Interno, 30p.

Vasconcellos P.M.P., Onoe A.T., Kawashita K., Soares A.J., Teixeira W. 2002. ${ }^{40} \mathrm{Ar}-{ }^{39} \mathrm{Ar}$ geochronology at the Instituto de Geociências, USP: instrumentation, analytical procedures and calibration. Anais da Academia Brasileira de Ciências, 74:297-342.

Yamato A.A. 1999. Mapeamento geológico de parte da Folha Bocaiúva do Sul (SG.22-X-D-I-2), escala 1:50.000. São Paulo, Dissertação de Mestrado, Instituto de Geociências, USP, 108p.

Manuscrito A-1630 Aceito em 23 de abril de 2007 